\title{
A comparative genomic and evolutionary analysis of circulating strains of Avian
} avulavirus 1 in Pakistan

\author{
Aziz-ul-Rahman ${ }^{1,3^{*}}$. Muhammad Munir ${ }^{2}$. Muhammad Zubair Shabbir ${ }^{3 *}$ \\ ${ }^{1}$ Department of Microbiology University of Veterinary and Animal Sciences Lahore 54600, \\ Pakistan; ${ }^{2}$ Division of Biomedical and Life Sciences, Lancaster University, Lancaster LA1 \\ 4YG United Kingdom; ${ }^{3}$ Quality Operations Laboratory University of Veterinary and Animal \\ Sciences Lahore 54600, Pakistan \\ *Corresponding authors: Both authors Aziz-ul-Rahman (drazizangel@gmail.com) and \\ Muhammad Zubair Shabbir (shabbirmz@uvas.edu.pk) equally contributed to this work. \\ ${ }^{1}$ ORCID: 0000-0002-3342-4462 \\ ${ }^{2}$ ORCID: 0000-0002-7889-1398 \\ ${ }^{3}$ ORCID: 0000-0002-3562-007X
}

\begin{abstract}
Newcastle disease, caused by Avian avulavirus 1 (AAvV 1), is endemic to many developing countries around the globe including Pakistan. Frequent epidemics are not uncommon even in vaccinated populations and are largely attributed to the genetic divergence of prevailing isolates and their transmission in the environment. With the strengthening of laboratory capabilities in Pakistan, a number of genetically diverse AAvV 1 strains have recently been isolated and individually characterized in comparison with isolates reported elsewhere in the world. However, there lacks sufficient comparative genomic and phylogenomic analyses of field circulating strains that can elucidate the evolutionary dynamics over a period of time. Herein, we enriched the whole genome sequences of $A A v V$ reported so far $(n=35)$ from Pakistan and performed comparative genomic, phylogenetic and evolutionary analyses. Based on these analyses, we found only isolates belonging to genotypes VI, VII and XIII of AAvV 1 in a wide range of avian and human hosts. Comparative phylogeny revealed the concurrent
\end{abstract}


circulation of avualviruses representing different sub-genotypes such as VIg, VIm, VIIa, VIIb, VIIe, VIIf, VIIi, XIIIb and XIIId. We found that that isolates of genotype VII were more closely associated with viruses of genotype XIII than genotype VI. An inter-genotype comparative residue analysis revealed a few substitutions in structurally and functionally important motifs. Putative recombination events were reported for only one of the captive-wild bird (pheasant)origin isolates. The viruses of genotype VII had high genetic diversity as compared to isolates from genotypes VI and XIII and, therefore, have more potential to evolve over time. Taken together, the current study provides an insight into the genetic diversity and evolutionary dynamics of AAvV 1 circulating in Pakistan. Such findings are expected to facilitate better intervention strategies for the prevention and control of ND in disease-endemic countries across the globe particularly Pakistan.

Keywords Avian avulavirus 1; genomic comparison; phylogenomic analysis; evolutionary dynamic; genetic diversity; genotypes and sub-genotypes

\section{Introduction}

Avian avulavirus 1 (AAvV 1) causes a highly contagious disease (Newcastle disease; ND) in commercial and backyard poultry with enormous economic impacts worldwide (Alexander 2003). The virus was recently classified as genus Orthoavulavirus within the family Paramyxoviridae (Kuhn et al. 2019). It has an enveloped, mono-partite, negative-sense singlestranded RNA genome that is potentially 15186,15192 or 15198 nucleotides in length (Kolakofsky et al. 2005). The whole genome contains six coding genes: nucleocapsid $(N)$, phosphoprotein $(P)$, matrix $(M)$, fusion $(F)$, haemagglutinin-neuraminidase $(H N)$ and large polymerase $(L)$ protein. These are encoded in the order 3'-NP-P/V/W-M-F-HN-L-5' (Aldous et al. 2003). Based on pathogenicity, the virus is categorized into three major pathotypes including velogenic, mesogenic and lentogenic (Alexander 1998). 
Phylogenetic analyses classified the viruses of AAvV 1 into two distinct classes; class-I and class-II. Class-I contains nine distinct genotypes (I-IX) of avirulent strains that share a 15198 nt long genome, while class-II contains at least eighteen distinct genotypes (I-XVIII) of high virulent, low virulent and avirulent strains that have a 15186 and/or $15192 \mathrm{nt}$ long genome (Aldous et al. 2003; Kim et al. 2007). Based on partial sequencing of $F$ genes (375bp between 4597-4972 nts), avualviruses of genotypes I, II, VI, VII, XIII are further divided into different sub-genotypes of both virulent and avirulent strains isolated from a wide range of avian species (Shabbir et al. 2012a, b, 2013, 2016; Munir et al. 2012a, b; Miller et al. 2015; Akhtar et al. 2016; Nath and Kumar 2015; Das and Kumar 2017, Xue et al. 2017; Barman et al. 2017; Habib et al. 2018; Aziz-ul-Rahman et al. 2018a, 2019).

ND is endemic to many parts of the globe including Pakistan. Similar to any other developing country, there exists a mixed poultry production system in Pakistan comprising of a large population of commercial and domestic poultry. Such a production system, which includes many birds being raised in backyard poultry farms and live bird markets, may favour the emergence of novel avulaviruses that may be divergent enough to be regarded as new subgenotypes or escape mutants. This is evident from the fact that despite exhaustive application of classical vaccines and biosecurity measures, a number of disease outbreaks are reported each year in multiple avian hosts. In this regard, a vast majority of studies in Pakistan have reported the epidemiology and surveillance of ND in commercial and domestic poultry and wild susceptible avian hosts. Historically, beginning in the 1990s, these studies were limited to serosurveillance (Numan et al. 2005; Aziz-ul-Rahman et al. 2017); whereas in recent years, partial genome-based studies have been conducted to investigate strain genotyping (Shabbir et al. 2012a, 2013; Munir et al. 2012b; Farooq et al. 2014; Akhtar et al. 2016, 2017; Wajid et al. 2018) while few studies involved in complete genome sequencing and biologic characterization 
of field circulating AAvV 1 strains (Munir et al. 2012a; Shabbir et al. 2012b, 2016, 2018; Habib et al. 2018; Aziz-ul-Rahman et al. 2018a, 2019).

Notably, each of these isolates are individually characterized based on a comparison of their genomic characteristics with avulaviruses reported elsewhere in the world, instead of countrywide reported complete genome sequences of avulaviruses originating from multiple hosts. Such analysis could provide baseline knowledge in understanding genetic diversity and evolutionary potential of circulating avulaviruses in a particular geographical setting over time. The resulting analysis may not only be used to inform the appropriate intervention for disease control and management, but may also be replicated for other settings across the globe with similar poultry-rearing systems.

\section{Materials and Methods}

\section{Database information}

To date (April, 2019), a total of 287 genome sequences corresponding to AAvV 1 from Pakistan are publicly available (http://www.ncbi.nlm.nih.gov/). These include complete genome $(\mathrm{n}=35)$ and partial $F$ gene $(\mathrm{n}=252)$ sequences including the hypervariable region reported from multiple avian hosts including commercial and backyard poultry, pigeons, captive- and migratory wild birds. All essential and relevant information about the complete genome were retrieved from these individual studies for the evolutionary and phylogenomic, comparative residue, and putative recombination analyses (Table 1).

\section{Phylogenetic analysis and evolutionary distance estimation}

The whole genome and partial $F$ gene sequences were aligned to corresponding sequences of avulaviruses representing different genotypes and sub-genotypes across the globe (GenBank) using ClustalW methods in BioEdit ${ }^{\circledR}$ version 5.0.6 (Hall 1999) for subsequent phylogenetic analysis, estimation of evolutionary distances and prediction of deduced amino acid 
substitution sites. To describe the topology of the phylogenetic tree, an analysis of the best fit substitution model was performed in $\mathrm{MEGA}^{\circledR}$ version 6.0 software, and the goodness of fit of the individual model was measured by corrected Akaine Information Criterion (AICc) and Bayesian Information Criterion (BIC) (Tamura et al. 2013). To reveal evolutionary dynamics of sub-genotypes, a time calibrated phylogenetic analysis was performed using two different models: the General Time Reversible model (GTR) with discrete gamma distribution $(+\mathrm{G})$ and the Real-Time-Maximum Likelihood model for invariant sites $(+\mathrm{I})$ in sequences. The evolutionary history was inferred by relative divergence time, and the statistical analysis was based on 1000 replication bootstrap values in $\mathrm{MEGA}^{\circledR}$ version 6.0 (Tamura et al. 2013). In this analysis, all positions containing gaps and/or missing codon were eliminated with codon positions as $1^{\text {st }}, 2^{\text {nd }}, 3^{\text {rd }}$ and non-coding.

To determine the nucleotide identity and divergence, Pairwise Sequence Comparisons (PASC) analysis was performed using whole genome sequences in MEGA ${ }^{\circledR}$ version 6.0 (Tamura et al. 2013). The mean inter-population evolutionary diversity (mean evolutionary distance) between sub-genotypes was estimated through PASC analysis using the maximum composite likelihood method (d: Transitions + Transversions model). The rate and pattern of substitutions among sites was modelled with gamma distribution (parameter=1 with homogenous lineage pattern) (Tamura and Kumar 2002). A few partial $F$ gene sequences representing different subgenotypes were used in this analysis. To further assess the evolutionary network of partial $F$ genes and, for identification of ancestor isolate and genotype, Splits Tree4 program (version 4.95) was employed using the Neighbour-Net graph method based on pairwise distances estimated by uncorrected $p$-distance and angle split transformation setting (Huson and Bryant 2006).

\section{Comparative residue analysis and selective pressure analysis}


ORF Finder and BioEdit were used to predict deduced amino acid sequences of all coding genes. A comparative residue alignment for identification of residue substitutions in conserved and functional motifs of all proteins of isolates from different genotypes (VI, VII, XIII) was created using graphic view option in BioEdit ${ }^{\circledR}$ version 5.0.6 (Hall 1999). Similarly, compared to vaccine strains (LaSota; AF077761, Mukteswar; EF201805), sub-genotype-based residue substitutions were also identified in partial $F$ gene sequences containing the hypervariable region using BioEdit. The Datamonkey adaptive evolution server (http://www.datamonkey.org/) was used to evaluate the nature of selection among coding DNA sequences (CDS) of all isolates (Delport et al. 2010). The positive and negative selection sites under natural selection were determined through three different genetic algorithms including Single Likelihood Ancestor Counting (SLAC), Fixed Effect Likelihood (FEL) and Fast Unbiased Bayesian Approximation (FUBAR) at Bayer factor $p=0.05$.

\section{Genetic diversity and genome based analysis for vaccine efficacy}

The genetic diversity among CDS of avulaviruses included in the study was assessed for genome polymorphism on the basis of variable sites and mutations and the average number of pairwise nucleotide differences identified using DnaSP version 5.10 .01 (http://www.ub.es/dnasp) (Librado and Rozas 2009). To demonstrate the departure from neutrality in all isolates, Tajima's D statistical method was used(Tajima 1989). For estimation of synonymous and non-synonymous substitution rates among CDS of all known NDV strains in genotype VI, VII and XIII against vaccine strains (LaSota, Mukteswar), synonymous and non-synonymous analysis program (SNAP v2.1.1) was used via an online webserver available at https://www.hiv.lanl.gov/content/sequence/SNAP/SNAP.html. The ratio and proportion of observed synonymous and non-synonymous substitutions was calculated by a statistical tool integrated into the webserver.

\section{Detection of putative recombination event}


For identification of putative breakpoints, recombination analysis was performed on all complete genome sequences of $35 \mathrm{AAvV} 1$ isolates using four different software, including SimPlot (Ray 2003), GARD (http://www.datamonkey.org/GARD), DAMBE (Xia 2001) and RDP4 version 4.95 (Martin et al. 2015). Initially, all isolates were used at once in order to check the possibility of the occurrence of recombination events. Later on, in order to exclude influence or ambiguousness of sequences shared among strains isolated from the same bird species at a time and reliability of analysis, individual isolates representing each species were used for each possible parental type at a time. Owing to the enhanced accuracy, clarity and reliability of the analysis, outcomes identified by RDP4 were considered conclusive for further interpretation. The RDP4 was preferred because it employs a combination of seven different algorithms (RDP, GENECONV, BootScan, MaxChi, Chimaera, SiScan and 3Seq) to better unleash putative recombinant and parent isolates at $p<0.001$. Putative recombination events were assumed to have occurred only when they were consistently identified by at least five of the above-mentioned seven algorithms at a probability threshold of 0.05 .

\section{Results}

\section{Genome characterization of all known Avian avulavirus 1}

A total of 35 whole genome sequences of AAvV 1 from multiple avian species [Chicken ( $\mathrm{n}=9)$, Pigeon $(n=8)$, Parrot $(n=5)$, Duck $(n=5)$, Peacock $(n=3)$, and Pheasant $(n=2)]$ and human $(n=$ 3) were acquired from a public database (Table 1) and analysed. As is typical for virulent strains, all isolates showed an identical cleavage motif $\left({ }_{112} R R Q K R \downarrow F_{117}\right)$ in the $F$ gene except for one isolate (KX236100), which contained a $\mathrm{K}$ to $\mathrm{R}$ residue substitution at position 115 (112RRQRR $\left.\downarrow F_{117}\right)$. All avian-originated isolate genomes were 15,192 nt in length except for one pigeon-originated isolate (KU885949), which was $15189 \mathrm{nt}$ long and contained deletions at positions 2125, 7103 and 8330 positions. Although these isolates had the same genome length, however, several insertions and deletions at different positions were observed in five 
different isolates, including KX236100 (pigeon, genotype VI), JX532092 (peacock, genotype VII), JX854452 (pheasant, genotype VII), JN682210 (chicken, genotype XIII) and JN682211 (chicken, genotype XIII). Important to note is that three of them originated from humans and had genome lengths ranging from 15146 to $15179 \mathrm{nt}$ with several insertions and deletions (Table 1). The PASC analysis for the entire genome revealed $0.01 \%-15.33 \%$ divergence among isolates from genotype VI, VII and XIII. This estimation revealed that avulaviruses of genotype VI and VII had maximum percent divergence (13.99\%-15.33\%) followed by $14.58 \%-14.73 \%$ between genotype VI and XIII, and 11.5\%-12.02\% between genotypes VII and XIII (Table 2).

\section{Phylogenetic analysis and evolutionary distance estimation}

Based on the whole genome sequences, the phylogenetic analysis clustered all isolates into three distinct genotypes; genotype VI, VII and XIII. Of $35 \mathrm{AAvV} 1$ isolates, 26 isolates were clustered in genotype VII with those reported from Indonesia (HQ697254), 4 isolates were clustered in genotype VI with those reported from China, and 5 isolates clustered in genotype XIII with isolates from India (Fig. 1). Furthermore, based on partial $F$ gene (375 bp) sequences, the phylogenetic analysis revealed that $\mathrm{AAvV}$ strains from genotype VII showed continuous evolution and clustered into five distinct sub-genotypes (VIIa, VIIb, VIIe, VIIf, VIIi) (Fig. 2A). The AAvVs from genotype VI were clustered into two distinct sub-genotypes (VIg and VIm) (Fig. 2B), whereas the avulaviruses from genotype XIII $(n=5)$ clustered into two sub-genotypes (XIIIb and XIIId) (Fig. 2C). The evolutionary network pattern of under study-isolates revealed distinct genetic diversity and diverse evolutionary relationships among sub-genotypes VI, VII and XIII (Fig. 3).

In Pakistan, all known avulaviruses of genotype VI belonged to only two sub-genotypes (VIg, VIm) and demonstrated $7.7 \%$ genetic distance with an overall range of $8.4 \%-11.3 \%$ and $7.7 \%$ $11.9 \%$ with other sub-genotypes, respectively (Table 3). Avulaviruses from VIIa revealed a high genetic distance (40.1\%) with viruses from VIIe followed by $35.4 \%$ between viruses from 
VIIe and VIIi, 33.9\% between viruses from VIIe and VIIf, 30.6\% between viruses from VIIb and VIIe, 25.1\% between viruses from VIIa and VIIb, 21.5\% between viruses from VIIa and VIIf, $19 \%$ between viruses from VIIb and VIIf, $16.2 \%$ between viruses from VIIf and VIIi, $15.2 \%$ between viruses from VIIb and VIIi and $6.8 \%$ between viruses from VIIa and VIIi (Table 4). Similar to genotype VI, avulaviruses of genotype XIII also belong to two subgenotypes (XIIIb, XIIId) and shared 3.9\% genetic distance to each other (Table 5).

\section{Comparative residue analysis}

Comparative residue analysis of all proteins of avulaviruses from genotype VI, VII and XIII revealed conservation in all functional motifs at the protein level. Few substitutions among strains from three genotypes were also found with the maximum number of substitutions in the $L$-gene (n=48), followed by the $F$ gene (n=32), $H N$ gene (n=28), $P$ gene ( $\mathrm{n}=16), M$ gene $(\mathrm{n}=13)$ and NP gene ( $\mathrm{n}=11)$ (Table 6). The inter-genotype comparative residue analysis revealed close relatedness between isolates from genotypes VII and XIII as compared to isolates from genotype VI. Using LaSota and Mukteswar as reference strains, partial $F$ gene sequences of avulaviruses included in this study representing different sub-genotypes were compared to each other and numerous substitutions were found at different positions. The cleavage site for all the strains was found to be identical except for a pigeon-originated isolate (KY042139, subgenotype VIg) which was identical to a mesogenic vaccine strain (EF201805) (Table 7).

\section{Genetic diversity and genome-based analysis for vaccine efficacy}

Based on individual coding genes, the DnaSP analysis revealed a high mutation rate in AAvVs isolates of genotype VII but high haplotype diversity was observed in CDS of isolates belonging to the VI genotype. Nucleotide diversity was found to be relatively higher in CDS of isolates belonging to genotype VI as compared to VII and XIII. For estimation based on the theory of neutrality in all CDS of isolates from individual genotypes, the Tajima's D value was found to be negative for all genes with $p>0.10$ except $P$ and $F$ genes of genotype XIII (Table 
8). An investigation of the synonymous and non-synonymous substitution rate against the vaccine strains revealed that CDS of isolates from all genotypes showed high synonymous and non-synonymous substitution rates when the LaSota strain was used a query compared to the Mukteswar strain (Table 9 and 10).

\section{Selective pressure analysis}

In the selective pressure analysis, none of coding genes from genotype VI had a mean $\mathrm{dN} / \mathrm{dS}$ greater than 1 at $p<0.05$ where the highest mean was observed for the $P$ gene $(0.37830)$ followed by the $H N(0.24668), L(0.13024), F(0.10890), M(0.10332)$ and $N P(0.05012)$ genes. Using three different statistical approaches (SLAC, FEL and IFEL), two positive selection sites were inferred by SLAC in the $P$ gene, whereas one was found in the $F$ gene. The FEL algorithm revealed three positive selection sites in the $F$ gene, two in the $P$ gene and one in the $N P$ gene. Similarly, using the IFEL algorithm, three positive sites were found in the $P$ gene, two in the $F$ gene and one in the $L$ gene. All coding genes of avulaviruses from genotype VII had a mean $\mathrm{dN} / \mathrm{dS}$ less than 1 at $p<0.05$ in the order of $F(0.38894)>H N(0.29408)>P(0.28340)>L$ $(0.13761)>P(0.098717)$ and $>M(0.01944)$. Using three different statistical algorithms, SLAC revealed two positive selection sites in the $F$ gene and only one in the NP gene. The FEL algorithm revealed seven positive selection sites in the $F$ gene, five in the $L$ gene and one each in the $H N$ and $P$ genes. In comparison, using the IFEL algorithm, numbers of positive selection sites as high as eleven in the $L$ gene, nine in the $F$ gene, three in the $H N$ gene, two in the $M$ gene, and one in the $P$ gene were observed. Similar to genotype VI and VII, none of the coding genes from isolates belonging to XIII had a mean $\mathrm{dN} / \mathrm{dS}$ greater than 1 at $p<0.05$ in the order $P(0.35729)>M(0.16906)>H N(0.16462)>F(0.14771)>L(0.10332)>N P$ (0.09096). Thus, only one positive selection site was found in the $F$ gene using the SLAC algorithm, while eleven positive sites were observed in the $L$ gene, five in the $F$ gene, three in the $H N$ and one in each the $N P$ and $P$ genes using the FEL algorithm. On the other hand, thirteen 
positive sites in $L$ gene, seven in $F$ gene, three in $H N$ gene, two in $N P$ gene and one in each $P$ and $M$ gene were inferred using the IFEL algorithm (Table 11).

\section{Recombination Analysis}

To identify novel recombinant events among isolates, all existing whole genomes of AAvVs were subjected to a detailed recombination analysis. However, only two putative recombination events (between 1008-3474 and 8818-9592 nt) (Fig. 4A, B) were observed in pheasantoriginated isolate (JX854452) with chicken-originated isolates. Noteworthy, both putative recombination events were observed in the same isolate sharing genomic sequence with same potential major parent (KP776462) from genotype VII and potential minor parent (JN682210) from genotype XIII. All seven recombination algorithm methods revealed the occurrence of recombination events in this isolate at $p<0.001$ value. The detailed information of inferred breakpoint and $p$-value of algorithm approaches are provided in Table 12.

\section{Discussion}

Given the importance of the $F$ gene in determining virulence of avulaviruses and conferring the major viral antigen, as well as the fact that current classification systems rely upon phylogenetic analysis of the same gene (Aldous et al. 2003; de Leeuw et al. 2003, 2005; Tsai et al. 2004; Kim et al. 2007), a large number of partial $F$ gene sequences from multiple avian hosts were available in GenBank and other public domains. Since $F$-gene-based analysis is insufficient to predict the true evolution of viruses, we performed the first-ever analysis highlighting the genomic and evolutionary aspects of whole genomes of countrywide circulating Avian avulavirus 1 strains. We performed this analysis because a specific gene might not evolve at the same rate as does the whole genome (Miller et al. 2009), and, therefore, our analysis can provide more comprehensive information to unleash virus evolution to serve as the basis for designing epidemiological investigations in the future. Additionally, the emergence of new strains in global epizootics and continuous evolution by year-to-year 
changes in genomic sequences can be investigated by complete genome analysis of avulaviruses isolated from different susceptible hosts. Because the vast genetic diversity may be favoured by the large variety of susceptible avian species and by the availability of highly mobile, wild/migratory waterfowl as natural reservoirs, continuous monitoring of viral evolution and molecular epidemiology of countrywide circulating avulaviruses is imperative for disease endemic countries such as Pakistan.

Across Pakistan, Avian avulavirus 1 strains of genotype VI (Akhtar et al. 2016; Shabbir et al. 2016), VII (Shabbir et al. 2012a, b, 2013, 2016; Munir et al., 2012a, b; Abbas et al. 2014; Farooq et al. 2014; Akhtar et al. 2016; Wajid et al. 2017; Habib et al. 2018; Aziz-ul-Rahman et al. 2018a, 2019) and XIII (Miller et al. 2015; Shabbir et al. 2018) have been reported previously from a wide range of hosts. Among these, avulaviruses of genotype XIII have not only been found responsible for outbreaks in poultry (Khan et al. 2010), but also have been implicated in mild respiratory infections in poultry workers (Shabbir et al. 2018). Apart from clinical infection, highly virulent avulaviruses of genotype VII were isolated from clinically healthy backyard poultry birds (Munir et al. 2012b), and asymptomatic wild- and water- fowl (Akhter et al. 2016, 2017; Habib et al. 2018; Aziz-ul-Rahman et al. 2018a, 2019).

Previous studies have suggested that the replacement of genotype XIII by genotype VII occurred between 2010 and 2013 (Khan et al. 2010; Miller et al. 2015). However, this claim is not convincing as new evidence suggests that the re-emergence of genotype XIII viruses isolated from humans is linked with poultry production settings (Shabbir et al. 2018). Such findings highlight the existence of genotype XIII viruses in the field and may suggest the need for revision of diagnostic assays that fail to detect these circulating viruses. The phylogenetic and evolutionary comparison of whole genome and partial $F$ gene sequences of humanoriginated genotype XIII to genotype XIIId, which is distinct from the previously reported genotype XIIIb from poultry, suggests continuous evolution of avulaviruses. For genotype VII, 
phylogenetic analyses of whole genome and partial $F$ gene sequences revealed that the current prevailing strains (since 2015) belong to sub-genotype VIIi and are evolutionarily similar to strains circulating in Israel, China and Indonesia (Shabbir et al. 2013a, b, 2016; Akhtar et al. 2016, 2017; Habib et al. 2018; Aziz-ul-Rahman et al. 2018a, 2019). The clustering of Pakistani avulaviruses originating from birds with isolates originating from Israel, China and Indonesia, highlight a continuous evolution and epizootic nature across the boundaries. It is important to note that equally virulent and genetically identical avulaviruses have also been isolated from multiple symptomatic and asymptomatic wild and captive avian species from Pakistan (Shabbir et al. 2012; Munir et al. 2012a, Qamar-un-Nisa et al. 2017, Akhtar et al. 2017), Israel and a public zoo in Mexico (Panshin et al. 2002; Miller et al. 2009). Therefore, the role of wild birds as natural reservoirs in dissemination of the virus cannot be overlooked. Recently, a spillover of AAvV 1 from wild to poultry and vice versa was investigated (Cardenas et al. 2013; Wajid et al. 2018). Most studies have reported outbreaks that occurred over short periods of time and were considered to be caused by accidental spillover of viruses (Vijayarani et al. 2010; Kumar et al. 2013; Dimitrov et al. 2016). Such an evidence of spill-over facilitates further evolution resulting in subsequent emergence of novel variant or escape mutant. These studies point out the significant role of different avian species, kept in captivity in poultry production settings in Pakistan, in virus dissemination. Although the current genetic diversity and evolutionary analyses reveal strong relationships among viruses originating from different avian species including poultry, limited information is available concerning the potential role of these avian species in the dissemination of virus.

The genetic diversity of avulaviruses, evidenced by synonymous and non-synonymous substitutions in residues of coding genes, has a crucial role in their evolution and subsequent adaptation to a wide range of hosts (Aziz-ul-Rahman et al. 2018b). Besides, previous studies showed evidence of evolution in $\mathrm{AAvV} 1$ under vaccine-induced immune pressure (Chong et 
al. 2010; Orabi et al. 2017). Considering the influence of vaccination on evolution, the genome sequence of vaccine strains commonly used in the field (LaSota; AF077761 and Mukteswar; EF201805) in Pakistan were selected for investigation of synonymous and non-synonymous substitutions in the current study. Comparative residue analysis of each gene of avulaviruses included in the study of genotype (VI, VII and XIII) with vaccine strains (genotype II and III) showed a number of synonymous and non-synonymous substitutions at varying substitution rates. However, a higher rate of non-synonymous substitution was more evident in avulaviruses of genotype VII and therefore, subsequent protection-challenge experiments are needed. This is important because the emergence of escape mutants over a period of time pose a major threat to the control of avulaviruses using classical vaccine due to decreased protection from challenge (Perozo et al. 2012; Ali et al. 2014; Farooq et al. 2014; Abbas et al. 2014; Umar et al. 2015). In fact, a high rate of non-synonymous substitutions in coding genes may alter the structural and biological function of viral proteins and the virus' subsequent virulence (Reitter et al. 1995). In this regard, a massive or irrational vaccine effort in the field may play a crucial role in the emergence of escape mutants such as those reported previously from vaccinates (Rehmani et al. 2015). The presence of virulent viruses in vaccinates in commercial farms (Rehmani et al. 2015) and their constant evolution over time (Miller et al. 2009) suggests the existence of a high environmental viral load with continuous replication in endemic countries. In addition, vaccine failure is correlated with substantial changes at the nucleotide level and genotype mismatching, which cause differences at essential immunodominant epitopes (Liu et al. 2018). Recently, a few studies on $F$ and $H N$ genes in avulaviruses of Pakistan revealed substitutions at both nucleotide and amino acid level at biologically and functionally important motifs (Shabbir et al. 2013a, b, 2016; Abbas et al. 2014; Akhtar et al. 2016, 2017; Habib et al. 2018; Aziz-ul-Rahman et al. 2018a, 2019). 
Besides residue substitutions, natural pressure selection sites in the genome are influenced by the environment and play a key role in virus evolution. High positive selection sites in CDS may affect the structure and function of the corresponding protein. The statistical calculation of non-synonymous and synonymous $(\mathrm{dN} / \mathrm{dS})$ mutations is significant in understanding the molecular evolution of CDS across closely related yet divergent strains. Datamonkey, in this regard, is a well-known web-server for rapid detection of positive ( $\mathrm{dN}>\mathrm{dS})$ and negative $(\mathrm{dN}<\mathrm{dS})$ selection sites in aligned CDS (Pond and Frost, 2005). Evidence of positive selection sites in all coding genes of inter- (genotype VI, VII and XIII) and intra-avulaviruses (AAvV 120) identified by SLAC, FEL and IFEL statistical approaches highlighted the underlying mechanism of virus evolution (Aziz-ul-Rahman et al. 2018b). Therefore, the emergence of strains representing novel sub-genotypes is possible in the near future. In our analysis, the mean $\mathrm{dN}-\mathrm{dS}$ were found to be non-significant with a minimum number of positive selection sites. While this seldom happens in structural domains of the genome, the impact of the combination of such positive selection sites with lower level sequence diversity may cause the emergence of variants (Yang et al. 2000). According to the neutral theory of molecular evolution, types of molecular variation that arise via spontaneous mutations have no influence on the virus' fitness (Fay and Wu 2003). Indeed, such substitutions might represent potential positive selection sites that could shape the virulence and evolution of new strains. However, the biological significance of these sites is still unknown, and it would be an area of interest to investigate the role of substitutions in pathogenicity using a reverse genetics approach.

The occurrence of recombination between strains may also potentially influence the evolution of avulaviruses (Qin et al. 2008; Satharasinghe et al. 2016) and, therefore may facilitate the emergence of novel/new mutant strains (Yin et al. 2011). In the present study, recombination analysis identified two potential recombination events in an avulavirus originating from pheasants with potential major (genotype VII) and minor parent strain (genotype XIII) of 
chicken origin. This is not surprising because recombination within avulaviruses of the same genotype (VII) (Han et al. 2008) and between two different genotypes (II and VII) (Qin et al., 2008) has previously been identified. The possibility of recombination between strains of the same and different genotypes highlights the potential impact of recombination on the emergence and evolution of novel avulaviruses. While the occurrence of natural recombination may facilitate the emergence of a novel/new mutant virus (Han et al. 2008; Qin et al., 2008), there is controversy in the interpretation of natural recombination. Previous studies suggested that recombination may play a vital role in AAvV 1 evolution (Zhang et al. 2010; Yin et al. 2011), while others concluded otherwise, referring to it as a sequencing artefact due to proofreading errors of the polymerase enzyme (Afonso 2008). That being said, recombination-based evolution in AAvVs is an on-going discussion and further studies are needed to understand its significance.

Based on all essential analyses, the current study concluded the concurrent evolution and circulation of avulaviruses of different sub-genotypes (VIg, VIm, VIIa, VIIb, VIIe, VIIf, VIIi, XIIIb and XIIId) in Pakistan, highlighting its evolutionary potential over a period of time. Evidences of positive selection sites and putative recombination events suggest increased genetic diversity among avulaviruses originating from multiple avian hosts. Taken together, this evidence may not only suggest the potential for the emergence of novel variants, but also the possibility of failure in diagnostics and vaccines. The evolutionary knowledge of genetic diversity of field prevailing avulaviruses impacts many aspects, from the broadest investigations of virus taxonomy, to the finest details of molecular epidemiology and vaccine design. Therefore, continuous monitoring and surveillance of viral evolution with necessary periodic updates should be ascertained for disease control interventions in disease-endemic countries.

\section{Acknowledgment}


We thank Ms. Juliette Rando (Medicine Department at University of Pennsylvania, USA) for critical reading and necessary edits in the manuscript text.

\section{Compliance with ethical standards}

Conflict of interest: The authors declare no conflict of interests.

Ethical approval: This article does not contain studies with animals or humans performed by any of the authors.

\section{Figure legends}

Fig. 1 Phylogenetic analysis of so-far reported complete genome sequences of Avian avulavirus 1 (highlighted with blue colour) from Pakistan. The neighbour-joining method with 1000 bootstraps was used for analysis of evolutionary relationship between and within isolates from different genotypes and representative isolates from worldwide using MEGA 6 software.

Fig. 2 Phylogenetic analysis based on partial $F$ gene sequences of so-far reported Avian avulavirus 1 (highlighted with blue colour) from Pakistan with representative isolates from worldwide using MEGA 6 software. The phylogeny analysis was conducted for classification of sub-genotypes within genotype VI (A), VII (B) and XIII (C).

Fig. 3 Partial $F$ gene sequence based evolutionary network of so-far reported Avian avulavirus 1 from Pakistan representing sub-genotypes-wise distribution of isolates.

Fig. 4 The plot display graphically illustrating the evidences underlying the detection of individual user-selected recombination event. The display depicting the coloured coded line representation of recombinant, major parent and minor parent isolates for the recombinant event 1 (A) and event 2 (B).

\section{References}

Abbas M, Shabbir MZ, Khaliq SA et al (2014) Sequence analysis of the hemagglutininneuraminidase gene of Newcastle disease virus from Punjab Pakistan. Adv Ani Vet Sci 2:242247. 
Afonso CL (2008) Not so fast on recombination analysis of Newcastle disease virus. J Virol 82:9303-9303.

Akhtar S, Muneer MA, Muhammad K et al (2016) Genetic characterization and phylogeny of pigeon paramyxovirus isolate (PPMV-1) from Pakistan. SpringerPlus 5(1):1295.

Akhtar S, Muneer MA, Muhammad K et al (2017) MoleculaCharacterization and Epitope Mapping of Fusion (F) and Hemagglutinin (HN) Genes of Avian Paramyxovirus Serotype I from Peacocks in Pakistan. Pakistan J Zool 49:755-759.

Aldous E, Mynn J, Banks J, Alexander D (2003) A molecular epidemiological study of avian paramyxovirus type 1 (Newcastle disease virus) isolates by phylogenetic analysis of a partial nucleotide sequence of the fusion protein gene. Avian Pathol 32:237-255.

Alexander DJ (1998) Newcastle disease virus and other avian paramyxoviruses, p. 156-163. In D. E. Swayne et al. (ed.), A laboratory manual for the isolation and identification of avian pathogens, 4th ed. American Association of Avian Pathologists, Kennett Square, PA.

Alexander DJ (2003) Newcastle disease virus, other avian paramyxoviruses, and pneumovirus infections. In: Saif YM, Barnes HJ, Glisson JR, Fadly AM, McDougald LR, Swayne DE, (eds) Disease of poultry, 11edn. Iowa State University Press, Ames, pp 63-87.

Ali M, Muneer B, Hussain Z et al (2014) Evaluation of efficacy of killed and commercially available live Newcastle disease vaccine in broiler chickens in Pakistan. J Ani Plant Sci 24:1663-1667.

Aziz-ul-Rahman, Habib M, Riaz T et al (2017) Seroprevalence of newcastle disease virus (NDV) in commercial and domesticated birds: Pakistan during current surge of NDV. J Inf Mol Biol 4(4):54-59.

Aziz-ul-Rahman, Munir M, Shabbir MZ (2018b) Comparative evolutionary and phylogenomic analysis of Avian avulaviruses 1 to 20. Mol Phyl Evol 127:931-51

Aziz-ul-Rahman, Yaqub T, Imran M, et al (2018a) Phylogenomics and Infectious Potential of Avian Avulaviruses Species-Type 1 Isolated from Healthy Green-Winged Teal (Anas carolinensis) from a Wetland Sanctuary of Indus River. Avian Dis 62(4):404-15.

Aziz-ul-Rahman, Yaqub T, Imran M, et al (2019) Sequence analysis and biological characterization of virulent Avian avulavirus 1 isolated from asymptomatic migratory fowls. Acta Virologica 63:181-186. https://doi.org/10.4149/av_2019 208

Barman LR, Nooruzzaman M, Sarker RD et al (2017) Phylogenetic analysis of Newcastle disease viruses from Bangladesh suggests continuing evolution of genotype XIII. Arch Virol 162(10):3177-82.

Cardenas GS, Navarro LR, Morales R et al (2013) Molecular epidemiology of Newcastle disease in Mexico and the potential spillover of viruses from poultry into wild bird species. Appl Environ Microbiol 79:4985-4992.

Chong YL, Padhi A, Hudson PJ et al (2010) The effect of vaccination on the evolution and population dynamics of avian paramyxovirus-1. PLoS Pathogens 22;6(4):e1000872. 
Das M, Kumar S (2017) Evidence of independent evolution of genotype XIII Newcastle disease viruses in India. Arch Virol 162(4):997-1007.

de Leeuw OS, Hartog L, Koch G, Peeters BPH (2003) Effect of fusion protein cleavage site mutations on virulence of Newcastle disease virus: non-virulent cleavage site mutants revert to virulence after one passage in chicken brain. J Gen Virol 84 (2):475-484.

de Leeuw OS, Koch G, Hartog L et al (2005) Virulence of Newcastle disease virus is determined by the cleavage site of the fusion protein and by both the stem region and globular head of the haemagglutinin-neuraminidase protein. J Gen Virol 86:1759-1769.

Delport W, Poon AF, Frost SD, Kosakovsky PSL (2010) Datamonkey 2010: a suite of phylogenetic analysis tools for evolutionary biology. Bioinformatics 26(19):2455-2457. doi:10.1093/bioinformatics/btq429

Dimitrov KM, Ramey AM, Qiu X et al (2016) Temporal, geographic, and host distribution of avian paramyxovirus 1 (Newcastle disease virus). Infect Genet Evol 39:22-34.

Farooq M, Saliha U, Munir M, Khan QM (2014) Biological and genotypic characterisation of the Newcastle disease virus isolated from disease outbreaks in commercial poultry farms in northern Punjab, Pakistan. Virol Reports 3:30-39.

Fay JC, Wu CI (2003) Sequence divergence, functional constraint, and selection in protein evolution. Annu. Rev Genom Hum Genet 4:213-235. doi:10.1146/annurev.genom.4.020303.162528

Habib M, Yaqub T, Nazir J et al (2018) Genomic and biological characterization of Newcastle disease viruses isolated from migratory mallards (Anas platyrhynchos). Arch Virol 30:1-10.

Hall TA (1999) BioEdit: a user-friendly biological sequence alignment editor and analysis program for Windows 95/98/NT. InNucleic acids symposium series No. 41:95-98.

Han GZ, He CQ, Ding NZ, Ma LY (2008) Identification of a natural multi-recombinant of Newcastle disease virus. Virol 371:54-60.

Huson DH, Bryant D (2006) Application of phylogenetic networks in evolutionary studies. Mol Bio Evol 23(2):254-67.

Khan TA, Rue CA, Rehmani SF et al (2010) Phylogenetic and biological characterisation of Newcastle disease virus isolates from Pakistan. J Clin Microbiol 48:1892-1894.

Kim LM, King DJ, Curry PE et al (2007) Phylogenetic diversity among low-virulence Newcastle disease viruses from waterfowl and shorebirds and comparison of genotype distributions to those of poultry-origin isolates. J Virol 81:12641-12653.

Kolakofsky D, Roux L, Garcin D, Ruigrok RW (2005) Paramyxovirus mRNA editing, the 'rule of six'and error catastrophe: a hypothesis. J Gen Virol 86:1869-1877.

Kuhn JH, Wolf YI, Krupovic M et al (2019) Classify viruses - the gain is worth the pain. Nature 566:318-320. doi:10.1038/d41586-019-00599-8 
Kumar A, Maan S, Mahajan NK et al (2013) Detection and molecular characterization of Newcastle disease virus in peafowl (Pavo cristatus) in Haryana State, India. Indian J Virol 24(3):380-385.

Librado P, Rozas J (2009) DnaSP v5: a software for comprehensive analysis of DNA polymorphism data. Bioinformatics 25(11):1451-1452. doi:10.1093/bioinformatics/btp187

Liu H, de Almeida RS, Gil P, Majó N, Nofrarías M, Briand FX, Jestin V, Albina E. Can genotype mismatch really affect the level of protection conferred by Newcastle disease vaccines against heterologous virulent strains?. Vaccine. 2018 Jun 22;36(27):3917-25.

Martin DP, Murrell B, Golden M et al (2015) RDP4: Detection and analysis of recombination patterns in virus genomes. Virus Evol 1(1).

Miller PJ, Haddas R, Simanov L et al (2015) Identification of new sub-genotypes of virulent Newcastle disease virus with potential panzootic features. Infec Genet Evol 29:216-229.

Miller PJ, Kim LM, Ip HS, Afonso CL (2009) Evolutionary dynamics of Newcastle disease virus. Virology 391(1):64-72.

Munir M, Cortey M, Abbas M et al (2012b) Phylogenetic analysis and biological characterization of a novel genetic group of Newcastle Disease Virus (NDV) isolated from outbreaks in commercial poultry farms and from healthy backyard poultry flocks. Infec Genet Evol 12:1010-1019.

Munir M, Shabbir MZ, Yaqub T et al (2012a) Complete genome sequence of a velogenic neurotropic avian paramyxovirus 1 isolated from Peacocks (Pavo cristatus) in a wildlife park in Pakistan. J Virol 86(23):13113-13114.

Nath B, Barman NN, Kumar S (2015) Molecular characterization of Newcastle disease virus strains isolated from different outbreaks in Northeast India during 2014-15. Microb Pathog 91:85-91.

Numan M, Zahoor MA, Khan HA, Siddique M (2005) Serologic status of Newcastle disease in broilers and layers in Faisalabad and surrounding districts. Pak Vet J 25(2):55.

Orabi A, Hussein A, Saleh AA et al (2017) Evolutionary insights into the fusion protein of Newcastle disease virus isolated from vaccinated chickens in 2016 in Egypt. Arch Virol 162(10):3069-79.

Panshin A, Shihmanter E, Weisman Y et al (2002) Antigenic heterogeneity among the field isolates of Newcastle disease virus (NDV) in relation to the vaccine strain: 1 . Studies on viruses isolated from wild birds in Israel. Comp Immunol Microbiol Infec Dis 25(2):95-108.

Perozo F, Marcano R, Afonso CL (2012) Biological and phylogenetic characterisation of a genotype VII Newcastle disease virus from Venezuela: efficacy of field vaccination. J Clin Microbiol 50:1204-1208.

Pond SL, Frost SD (2005) Datamonkey: rapid detection of selective pressure on individual sites of codon alignments. Bioinformatics 21(10):2531-2533. doi:10.1093/bioinformatics/bti320 
Qamar-un-Nisa, Younus M, Muti-ur-Rehman et al (2017) Pathological Alterations during CoInfection of Newcastle Disease Virus with Escherichia coli in Broiler Chicken. Pak J Zool 49:1953-1961.

Qin Z, Sun L, Ma B et al (2008) F gene recombination between genotype II and VII Newcastle disease virus. Virus Res 131(2):299-303.

Ray SC (2003) SimPlot for Windows (version 3.5.1). Baltimore MD: Available online at: http://sray.med.som.jhmi.edu/SCRoftware/ (Accessed June 2015)

Rehmani SF, Wajid A, Bibi T et al (2015) Presence of virulent Newcastle disease virus in vaccinated chickens in farms in Pakistan. J Clin Microbiol 53:1715-8. https://doi.org/10.1128/JCM.02818-14

Reitter JN, Sergel T, Morrison TG (1995) Mutational analysis of the leucine zipper motif in the Newcastle disease virus fusion protein. J Virol 69:5995-6004.

Satharasinghe DA, Murulitharan K, Tan SW et al (2016) Detection of inter-lineage natural recombination in avian paramyxovirus serotype 1 using simplified deep sequencing platform. Fron Microbiol 7:1907.

Shabbir MZ, Abbas M, Yaqub T et al (2012a) Genetic analysis of Newcastle disease virus from Punjab, Pakistan. Virus Genes 46:309-315.

Shabbir MZ, Akhtar S, Tang Y et al (2016) Infectivity of wild bird origin Avian Paramyxovirus serotype 1 and vaccine effectiveness in chickens. J Gen Virol 97(12):3161-3173. DOI: 10.1099/jgv.0.000618

Shabbir MZ, Goraya MU, Abbas M et al (2012b) Complete genome sequencing of a velogenic viscerotropic avian paramyxovirus 1 isolated from pheasants (Pucrasia macrolopha) in Lahore, Pakistan. J Viro 86(24):13828-13829.

Shabbir MZ, Nissly RH, Ahad A et al (2018) Complete Genome Sequences of Three Related Avian Avulavirus 1 Isolates from Poultry Farmers in Pakistan. Genome announc 6(18):e0036118.

Shabbir MZ, Zohari S, Yaqub T et al (2013) Genetic diversity of Newcastle disease virus in Pakistan: A countrywide perspective. Viro J 10:170-179.

Tajima F (1989) Statistical method for testing the neutral mutation hypothesis by DNA polymorphism. Genetics 123(3):585-595.

Tamura K, Kumar S (2002) Evolutionary distance estimation under heterogeneous substitution pattern among lineages. Mol Biol Evol 19:1727-1736.

Tamura K, Stecher G, Peterson D et al (2013) MEGA6: molecular evolutionary genetics analysis version 6.0. Mol Biol Evol 30:2725-2729.

Tsai H-J, Chang K-H, Tseng C-H et al (2004) Antigenic and genotypical characterization of Newcastle disease viruses isolated in Taiwan between 1969 and 1996. Vet Microbiol 104(12):19-30. 
Umar S, Younus M, Arshad HU et al (2015) Recent advances in vaccination strategies and future perspectives for the control of Newcastle disease in Pakistan: A review. Intern J Vet Sci $4: 136-141$.

Vijayarani K, Muthusamy S, Tirumurugaan KG et al (2010) Pathotyping of a Newcastle disease virus isolated from peacock (Pavo cristatus). Trop Anim. Health Prod 42:415-419.

Wajid A, Dimitrov KM, Wasim M et al (2017) Repeated isolation of virulent Newcastle disease viruses in poultry and captive non-poultry avian species in Pakistan from 2011 to 2016. Pre Vet Med 142:1-6.

Wajid A, Dundon WG, Hussain T, Babar ME (2018) Pathotyping and genetic characterization of avian avulavirus-1 from domestic and wild waterfowl, geese and black swans in Pakistan, 2014 to 2017. Arch Virol 2:1-6.

Xia X, Xie Z (2001) DAMBE: software package for data analysis in molecular biology and evolution. J Hered 92(4):371-3.

Xue C, Cong Y, Yin R et al (2017) Genetic diversity of the genotype VII Newcastle disease virus: identification of a novel VIIj sub-genotype. Virus Genes 53(1):63-70.

Yang Z, Nielsen R, Goldman N, Pedersen AM (2000) Codon substitution models for heterogeneous selection pressure at amino acid sites. Genetics 155(1):431-449.

Yin Y, Cortey M, Zhang Y et al (2011) Molecular characterization of Newcastle disease viruses in Ostriches (Struthio camelus L.): further evidences of recombination within avian paramyxovirus type 1. Vet Microbiol 149(3):324-9.

Zhang R, Wang X, Su J et al (2010) Isolation and analysis of two naturally-occurring multirecombination Newcastle disease viruses in China. Virus Res 151:45-53. 
Table 1: Detailed information of whole genomes sequences of Avian avulavirus 1 isolated from different birds in Pakistan

\begin{tabular}{|c|c|c|c|c|c|c|c|c|c|}
\hline $\begin{array}{l}\text { Sr. } \\
\text { No. }\end{array}$ & $\begin{array}{c}\text { Accession } \\
\text { numbers }\end{array}$ & $\begin{array}{l}\text { Year of } \\
\text { isolation }\end{array}$ & Host & Location & $\begin{array}{l}\text { Genome } \\
\text { length } \\
\text { (bp) }\end{array}$ & $\begin{array}{c}\text { Insertion and deletion } \\
\text { of nucleotides in } \\
\text { genome }\end{array}$ & $\begin{array}{c}\text { Cleavage site } \\
\text { pattern }\end{array}$ & Genotype & $\begin{array}{c}\text { Sub- } \\
\text { genotype }\end{array}$ \\
\hline 1 & KX268690 & 2016 & Parakeet & Lahore & 15192 & $\mathrm{NO}$ & ${ }_{112} \mathrm{RRQKR} \downarrow \mathrm{F}_{117}$ & VII & VIIi \\
\hline 2 & KX268691 & 2016 & Parakeet & Lahore & 15192 & $\mathrm{NO}$ & ${ }_{112} \mathrm{RRQKR} \downarrow \mathrm{F}_{117}$ & VII & VIIi \\
\hline 3 & KX791183 & 2016 & Parakeet & Rawalpindi & 15192 & $\mathrm{NO}$ & ${ }_{112} \mathrm{RRQKR} \downarrow \mathrm{F}_{117}$ & VII & VIIi \\
\hline 4 & KX791184 & 2016 & Backyard poultry & Lahore & 15192 & $\mathrm{NO}$ & ${ }_{112} \mathrm{RRQKR} \downarrow \mathrm{F}_{117}$ & VII & VIIi \\
\hline 5 & KX791185 & 2016 & Backyard poultry & Lahore & 15192 & $\mathrm{NO}$ & ${ }_{112} \mathrm{RRQKR} \downarrow \mathrm{F}_{117}$ & VII & VIIi \\
\hline 6 & KX791186 & 2016 & Backyard poultry & Lahore & 15192 & $\mathrm{NO}$ & ${ }_{112} \mathrm{RRQKR} \downarrow \mathrm{F}_{117}$ & VII & VIIi \\
\hline 7 & KX791187 & 2016 & Backyard poultry & Lahore & 15192 & $\mathrm{NO}$ & ${ }_{112} \mathrm{RRQKR} \downarrow \mathrm{F}_{117}$ & VII & VIIi \\
\hline 8 & KX791188 & 2016 & Backyard poultry & Lahore & 15192 & $\mathrm{NO}$ & ${ }_{112} \mathrm{RRQKR} \downarrow \mathrm{F}_{117}$ & VII & VIIi \\
\hline 9 & KY697611 & 2016 & Mallard & Mianwali & 15192 & $\mathrm{NO}$ & ${ }_{112} \mathrm{RRQKR} \downarrow \mathrm{F}_{117}$ & VII & VIIi \\
\hline 10 & KY697612 & 2016 & Mallard & Mianwali & 15192 & $\mathrm{NO}$ & ${ }_{112} R_{R Q K R} \downarrow F_{117}$ & VII & VIIi \\
\hline 11 & MH019281 & 2015 & Human & Lahore & 15167 & $\begin{array}{c}\text { Deletion at }(1-14,8329, \\
15182-15192) \text { position }\end{array}$ & ${ }_{112} \mathrm{RRQKR} \downarrow \mathrm{F}_{117}$ & XIII & XIIId \\
\hline 12 & MH019282 & 2015 & Human & Lahore & 15179 & $\begin{array}{c}\text { Insertion at }(1724-1735) \\
\text { deletion at }(1-9,1724- \\
1735,8329,15182- \\
15192) \text { position }\end{array}$ & ${ }_{112} \mathrm{RRQKR} \downarrow \mathrm{F}_{117}$ & XIII & XIIId \\
\hline 13 & MH019283 & 2015 & Human & Lahore & 15146 & $\begin{array}{c}\text { Deletion at }(1-14,1697- \\
1716,8329,15182- \\
15192) \text { position }\end{array}$ & ${ }_{112} \mathrm{RRQKR} \downarrow \mathrm{F}_{117}$ & XIII & XIIId \\
\hline 14 & KX268688 & 2015 & Parakeet & Rawalpindi & 15192 & $\mathrm{NO}$ & ${ }_{112} \mathrm{RRQKR} \downarrow \mathrm{F}_{117}$ & VII & VIIi \\
\hline 15 & KX268689 & 2015 & Parrot & Lahore & 15192 & $\mathrm{NO}$ & ${ }_{112} \mathrm{RRQKR} \downarrow \mathrm{F}_{117}$ & VII & VIIi \\
\hline 16 & KY290560 & 2015 & Peacock & Lahore & 15192 & $\mathrm{NO}$ & ${ }_{112} \mathrm{RRQKR} \downarrow \mathrm{F}_{117}$ & VII & VIIi \\
\hline 17 & KY290561 & 2015 & Pheasant & Lahore & 15192 & $\mathrm{NO}$ & ${ }_{112} \mathrm{RRQKR} \downarrow \mathrm{F}_{117}$ & VII & VIIi \\
\hline 18 & KU845252 & 2015 & Duck & Lahore & 15192 & $\mathrm{NO}$ & ${ }_{112} \mathrm{RRQKR} \downarrow \mathrm{F}_{117}$ & VII & VIIi \\
\hline 19 & MF437286 & 2015 & $\begin{array}{c}\text { Green-winged } \\
\text { teal }\end{array}$ & Mianwali & 15192 & NO & ${ }_{112} \mathrm{RRQKR} \downarrow \mathrm{F}_{117}$ & VII & VIIi \\
\hline 20 & MF437287 & 2015 & $\begin{array}{c}\text { Green-winged } \\
\text { teal } \\
\end{array}$ & Mianwali & 15192 & NO & ${ }_{112} \mathrm{RRQKR} \downarrow \mathrm{F}_{117}$ & VII & VIIi \\
\hline 21 & KX236100 & 2015 & Pigeon & Lahore & 15192 & $\begin{array}{c}\text { Insertion at } 1631 \\
\text { position and deletion at } \\
2015 \text { position }\end{array}$ & ${ }_{112} \mathrm{RRQRR} \downarrow \mathrm{F}_{117}$ & VI & VIm \\
\hline 22 & KX496962 & 2015 & Pigeon & Lahore & 15192 & $\mathrm{NO}$ & ${ }_{112} \mathrm{RRQKR} \downarrow \mathrm{F}_{117}$ & VII & VIIi \\
\hline 23 & KX496963 & 2015 & Pigeon & Lahore & 15192 & $\mathrm{NO}$ & ${ }_{112} \mathrm{RRQKR} \downarrow \mathrm{F}_{117}$ & VII & VIIi \\
\hline 24 & KX496964 & 2015 & Pigeon & Lahore & 15192 & $\mathrm{NO}$ & ${ }_{112} \mathrm{RRQKR} \downarrow \mathrm{F}_{117}$ & VII & VIIi \\
\hline 25 & KX496965 & 2015 & Pigeon & Lahore & 15192 & $\mathrm{NO}$ & ${ }_{112} \mathrm{RRQKR}_{\downarrow} \mathrm{F}_{117}$ & VII & VIIi \\
\hline 26 & KY042135 & 2015 & Pigeon & Lahore & 15192 & $\mathrm{NO}$ & ${ }_{112} \mathrm{RRQKR} \downarrow \mathrm{F}_{117}$ & $\mathrm{VI}$ & VIm \\
\hline 27 & KX236101 & 2015 & Pigeon & Lahore & 15192 & $\mathrm{NO}$ & ${ }_{112} \mathrm{RRQKR} \downarrow \mathrm{F}_{117}$ & VI & VIm \\
\hline 28 & KU885949 & 2014 & Pigeon & NA & 15189 & $\begin{array}{l}\text { Deletion at } 2125,7103 \\
\text { and } 8330 \text { position }\end{array}$ & ${ }_{112} \mathrm{RRQKR} \downarrow \mathrm{F}_{117}$ & VI & VIm \\
\hline 29 & KP776462 & 2014 & $\begin{array}{c}\text { Commercial } \\
\text { Poultry }\end{array}$ & NA & 15192 & $\mathrm{NO}$ & ${ }_{112} \mathrm{RRQKR} \downarrow \mathrm{F}_{117}$ & VII & VIIi \\
\hline 30 & KU885948 & 2014 & Peacock & NA & 15192 & $\mathrm{NO}$ & ${ }_{112} \mathrm{RRQKR} \downarrow \mathrm{F}_{117}$ & VII & VIIi \\
\hline 31 & KM670337 & 2013 & $\begin{array}{l}\text { Vaccinated } \\
\text { Chicken } \\
\end{array}$ & NA & 15192 & NO & ${ }_{112} \mathrm{RRQKR} \downarrow \mathrm{F}_{117}$ & VII & VIIi \\
\hline 32 & JX532092 & 2012 & Peacock & Lahore & 15192 & $\begin{array}{l}\text { Insertion at } 2130 \text { and } \\
7057 \text { position, deletion } \\
\text { at } 2125 \text { and } 7103 \\
\text { position }\end{array}$ & ${ }_{112} \mathrm{RRQKR} \downarrow \mathrm{F}_{117}$ & VII & VIIa \\
\hline 33 & JX854452 & 2011 & Pheasant & NA & 15192 & $\begin{array}{l}\text { Insertion at } 7057 \text { and } \\
8329 \text { position, deletion } \\
\text { at } 2125 \text { and } 7103 \\
\text { position }\end{array}$ & ${ }_{112} \mathrm{RRQKR} \downarrow \mathrm{F}_{117}$ & VII & VIIa \\
\hline 34 & JN682210 & 2010 & $\begin{array}{l}\text { Commercial } \\
\text { Poultry }\end{array}$ & Rawalpindi & 15192 & $\begin{array}{c}\text { Insertion at }(1686-1690 \\
8336) \text { and deletion at } \\
(1649-1653,8330) \\
\text { position }\end{array}$ & ${ }_{112} \mathrm{RRQKR} \downarrow \mathrm{F}_{117}$ & XIII & XIIIb \\
\hline 35 & JN682211 & 2010 & $\begin{array}{l}\text { Commercial } \\
\text { Poultry }\end{array}$ & Rawalpindi & 15192 & $\begin{array}{c}\text { Insertion at } 8336 \\
\text { position and deletion at } \\
8330 \text { position }\end{array}$ & ${ }_{112} \mathrm{RRQKR} \downarrow \mathrm{F}_{117}$ & XIII & XIIIb \\
\hline
\end{tabular}


1 Table 2: Estimation of percent divergence for complete genomes sequences of so-far reported Avian avulavirus 1 from Pakistan

\begin{tabular}{|c|c|c|c|c|c|c|c|c|c|c|c|c|c|c|c|c|c|c|c|c|c|c|c|c|c|c|c|c|c|c|c|c|c|c|c|}
\hline $\begin{array}{l}\text { Accession } \\
\text { numbers }\end{array}$ & 高 & 翖 & $\begin{array}{l}\frac{\not{z}}{\bar{z}} \\
\underline{\underline{z}}\end{array}$ & 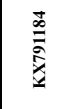 & $\begin{array}{l}\frac{0}{8} \\
\frac{2}{2}\end{array}$ & & 产 & 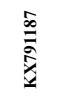 & $\begin{array}{l}\frac{80}{20} \\
\frac{2}{2} \\
\frac{1}{2}\end{array}$ & 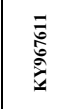 & 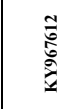 & 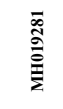 & 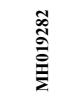 & 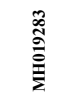 & 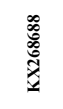 & 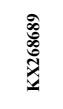 & 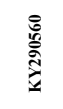 & 哀 & 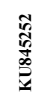 & 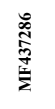 & 竧 & 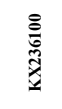 & 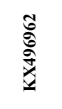 & $\begin{array}{l}\frac{8}{2} \\
\frac{2}{2} \\
\frac{2}{2}\end{array}$ & 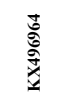 & 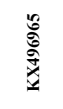 & 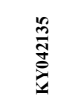 & 产 & 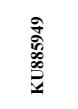 & 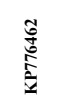 & 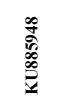 & 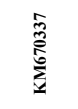 & 商 & 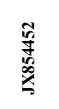 & 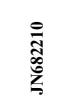 \\
\hline $\begin{array}{l}K \times 268690 \\
K \times 268991\end{array}$ & & & & & & & & & & & & & & & & & & & & & & & & & & & & & & & & & & & \\
\hline 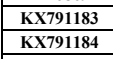 & $\begin{array}{l}0.048 \\
0.48 \\
132\end{array}$ & $\frac{0.48}{1.32}$ & 1.17 & & & & & & & & & & & & & & & & & & & & & & & & & & & & & & & & \\
\hline 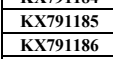 & $\begin{array}{l}1.35 \\
1.33\end{array}$ & $\begin{array}{l}1.35 \\
1.33\end{array}$ & $\begin{array}{l}1.20 \\
.118 \\
\end{array}$ & \begin{tabular}{|l|l|}
0.07 \\
0.05
\end{tabular} & 0.06 & & & & & & & & & & & & & & & & & & & & & & & & & & & & & & \\
\hline \begin{tabular}{|l}
$x 791187$ \\
$x 791188$
\end{tabular} & $\begin{array}{l}1.32 \\
\end{array}$ & 1.32 & $\begin{array}{l}1.17 \\
\end{array}$ & \begin{tabular}{|l|l}
0.03 \\
\end{tabular} & \begin{tabular}{|l}
0.05 \\
\end{tabular} & & 1.03 & & & & & & & & & & & & & & & & & & & & & & & & & & & & \\
\hline 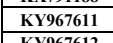 & $\begin{array}{l}1.53 \\
.76\end{array}$ & $\begin{array}{l}1.53 \\
.76\end{array}$ & $\frac{1.10}{1.65}$ & $\frac{0.05}{1.08}$ & $\frac{0.30}{1.08}$ & & 1.08 & $\frac{.03}{1.08}$ & 1.08 & & & & & & & & & & & & & & & & & & & & & & & & & & \\
\hline$\frac{67612}{67012}$ & $\begin{array}{l}1.77 \\
\end{array}$ & $\begin{array}{l}1.77 \\
\end{array}$ & $\begin{array}{l}1.65 \\
\end{array}$ & $\frac{1.08}{1.08}$ & 1.08 & & 1.09 & $\begin{array}{ll}1.08 \\
\end{array}$ & $\begin{array}{l}1.09 \\
\end{array}$ & \begin{tabular}{|l|l|} 
\\
.033
\end{tabular} & & & & & & & & & & & & & & & & & & & & & & & & & \\
\hline & $\frac{11.91}{11.91}$ & $\frac{11.8}{11.8}$ & $\frac{11.79}{1.18}$ & $\frac{1.192}{1.192}$ & $\frac{1.195}{11.95}$ & & 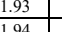 & $\frac{11.92}{110.93}$ & \begin{tabular}{|l|l|}
11.93 \\
\end{tabular} & 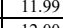 & $\frac{12.00}{1201}$ & & & & & & & & & & & & & & & & & & & & & & & & \\
\hline & $\frac{1.31}{1191}$ & $\frac{11.8}{1118}$ & $\frac{11.69}{11.79}$ & $\frac{1.195}{11.29}$ & \begin{tabular}{|l|l|}
1.195 \\
19
\end{tabular} & & 1.93 & 1192 & 41.94 & \begin{tabular}{|l|l|l|}
11.99 \\
\end{tabular} & $\frac{12.00}{12.00}$ & $\frac{0.01}{0.00}$ & 0.01 & & & & & & & & & & & & & & & & & & & & & & \\
\hline 40989 & 0.51 & 0.51 & 0.03 & $\frac{1.15}{1.15}$ & $\begin{array}{l}1.18 \\
\end{array}$ & & 1.16 & 1.15 & $\begin{array}{l}1.16 \\
\end{array}$ & \begin{tabular}{|l|l|l|} 
\\
\end{tabular} & $\begin{array}{l}1.63 \\
\end{array}$ & $\begin{array}{l}111.79 \\
\end{array}$ & 11.80 & & & & & & & & & & & & & & & & & & & & & & \\
\hline 286889 & $\begin{array}{l}0.10 \\
1.17\end{array}$ & $\begin{array}{l}0.10 \\
117\end{array}$ & $\begin{array}{l}0.43 \\
.40\end{array}$ & 1.28 & 1.30 & & . & 1.28 & 1.28 & \begin{tabular}{|l|l}
1.71 \\
\end{tabular} & $\begin{array}{l}1.72 \\
1.42\end{array}$ & $\begin{array}{l}11.87 \\
1.76\end{array}$ & $\begin{array}{l}11.88 \\
\end{array}$ & $\begin{array}{ll}11.87 \\
11.76\end{array}$ & 0.44 & & & & & & & & & & & & & & & & & & & & \\
\hline & $\frac{1.114}{1.14}$ & $\frac{1.114}{1.14}$ & $\frac{1.04}{1.02}$ & $\frac{1.1}{1.06}$ & $\frac{1.12}{1.09}$ & & 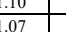 & $\frac{1.1}{1.06}$ & \begin{tabular}{|l|l|l|}
1.07 \\
\end{tabular} & \begin{tabular}{|l|l|l|}
1.42 \\
\end{tabular} & $\frac{1.46}{1.42}$ & $\frac{11.16}{11.73}$ & $\frac{11.76}{11.73}$ & $\frac{11.16}{11.73}$ & $\frac{1.120}{10.00}$ & $\frac{1.12}{1.10}$ & 0.14 & & & & & & & & & & & & & & & & & & \\
\hline 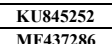 & 0.66 & 0.66 & 0.32 & 1.24 & 1.26 & \begin{tabular}{|l|l}
5 & 1.2 \\
\end{tabular} & 1.24 & 1.24 & 1.24 & \begin{tabular}{|l|l}
1.58 \\
\end{tabular} & 1.58 & 11.82 & 11.83 & 11.82 & 0.30 & 0.60 & 0.00 .92 & 0.88 & 157 & & & & & & & & & & & & & & & & \\
\hline 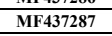 & 1.74 & 1.74 & $\frac{1.64}{1.63}$ & $\frac{1.07}{1.06}$ & $\frac{1.10}{1.06}$ & & 1.0 & $\frac{1.07}{1.06}$ & \begin{tabular}{|l|l|}
1.08 \\
\end{tabular} & \begin{tabular}{|l|}
0.13 \\
0.11
\end{tabular} & 0.09 & $\frac{22.01}{12.01}$ & $\frac{12.02}{12.02}$ & $\frac{12.01}{12.01}$ & & $\begin{array}{l}1.11 \\
1.69 \\
\end{array}$ & $\frac{1.44}{1.43}$ & & 1.56 & & & & & & & & & & & & & & & & \\
\hline KX236100 & $\begin{array}{l}14.32 \\
\end{array}$ & $\begin{array}{l}14.32 \\
\end{array}$ & 14.25 & $\frac{14.41}{1.1}$ & 14.45 & & $\begin{array}{l}4.41 \\
\end{array}$ & 14.39 & \begin{tabular}{|l|l|}
144.11 \\
\end{tabular} & \begin{tabular}{|l|l|}
14.42 \\
\end{tabular} & 144.43 & $\begin{array}{l}14.65 \\
\end{array}$ & $\begin{array}{l}14.66 \\
\end{array}$ & $\begin{array}{l}14.65 \\
\end{array}$ & 14.25 & 14,30 & 14,21 & 14,21 & 14.25 & 14.45 & 14.45 & & & & & & & & & & & & & & \\
\hline & 0.76 & 0.76 & 0.64 & 0.9 & 0.93 & & .9.91 & 0.90 & \begin{tabular}{|l|l|}
0.91 \\
\end{tabular} & \begin{tabular}{|l|l|} 
\\
1.16
\end{tabular} & 1.17 & 11.54 & $\begin{array}{l}11.55 \\
\end{array}$ & 11.54 & 0.62 & 0.72 & 0.64 & 0.62 & 0.64 & 1.16 & 1.14 & \begin{tabular}{|l|l|}
114.00 \\
\end{tabular} & & & & & & & & & & & & & \\
\hline 496964 & $\frac{1.07}{0.76}$ & $\frac{1.96}{0.76}$ & 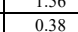 & 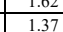 & 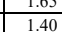 & & 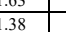 & $\frac{1.02}{1.177}$ & $\begin{array}{l}\frac{1.03}{1.38} \\
\end{array}$ & \begin{tabular}{|l|l|}
1.30 \\
\end{tabular} & $\frac{1.37}{1.72}$ & $\frac{1.201}{11.79}$ & $\frac{1.202}{11.79}$ & $\frac{1.101}{11.79}$ & $\frac{1.04}{0.036}$ & $\frac{1.050}{0.07}$ & $\frac{1.02}{1.24}$ & $\frac{0.92}{1.22}$ & $\frac{1.537}{0.037}$ & $\frac{1.93}{1.71}$ & $\frac{\mid 1.72}{1.69}$ & \begin{tabular}{|l}
14.45 \\
14.27
\end{tabular} & $\frac{1.164}{0.64}$ & & & & & & & & & & & & \\
\hline $\begin{array}{l}496965 \\
44092155\end{array}$ & 0.76 & 0.76 & \begin{tabular}{|l|l|l} 
\\
\end{tabular} & 1.37 & \begin{tabular}{|l|l}
.40 \\
1.10
\end{tabular} & & 1.38 & $\begin{array}{l}1.37 \\
1.10\end{array}$ & $\begin{array}{l}1.38 \\
14.1\end{array}$ & \begin{tabular}{|l|l}
1.71 \\
1.28
\end{tabular} & 1.72 & \begin{tabular}{|l|l|l|}
11.79 \\
\end{tabular} & $\begin{array}{l}11.79 \\
1.772\end{array}$ & $\begin{array}{l}11.79 \\
11.72\end{array}$ & 0.36 & $\begin{array}{l}0.70 \\
\end{array}$ & $\begin{array}{l}1.24 \\
1.24\end{array}$ & 1.22 & \begin{tabular}{|l|l|l}
0.37 \\
\end{tabular} & $\begin{array}{l}1.71 \\
1.19\end{array}$ & $\begin{array}{l}1.69 \\
\end{array}$ & \begin{tabular}{|l|l|}
14.27 \\
\end{tabular} & \begin{tabular}{|l|l|l}
0.64 \\
\end{tabular} & $\begin{array}{l}1.7 \\
1.14\end{array}$ & 0.00 & 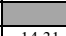 & & & & & & & & & \\
\hline 200101 & & & & & & & 4.31 & & \begin{tabular}{|l|l|l|l|l|}
14.31 \\
\end{tabular} & \begin{tabular}{|l|l|l|l|l}
14.40 \\
\end{tabular} & \begin{tabular}{|l|l|l|}
14.41 \\
\end{tabular} & & $\begin{array}{l}14.73 \\
14.48\end{array}$ & $\frac{14.12}{14.47}$ & & & & $\frac{14.24}{14.15}$ & & $\begin{array}{l}44.42 \\
14.41\end{array}$ & & & \begin{tabular}{|l|}
13.00 \\
13.94 \\
\end{tabular} & & & & 3.89 & & & & & & & & \\
\hline KL8859499 & 14.29 & 14.29 & $\begin{array}{l}14.24 \\
\end{array}$ & 14.45 & 144.48 & & 4.45 & 14,43 & 14.45 & \begin{tabular}{|l|l|}
14.38 \\
\end{tabular} & $\begin{array}{l}144.41 \\
\end{array}$ & $\begin{array}{l}14.58 \\
\end{array}$ & $\begin{array}{l}14.58 \\
\end{array}$ & $\begin{array}{l}14.58 \\
\end{array}$ & 14.23 & $\begin{array}{l}14.27 \\
\end{array}$ & 14.20 & 14.20 & 14.22 & 144.43 & 144.42 & \begin{tabular}{|l|l|l|} 
\\
\end{tabular} & \begin{tabular}{|l|l|}
13.99 \\
\end{tabular} & $\begin{array}{l}14.44 \\
\end{array}$ & 14.25 & \begin{tabular}{|l|l|}
14.25 \\
\end{tabular} & 1.85 & 3.8 & & & & & & & \\
\hline 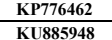 & $\begin{array}{l}1.08 \\
1.43\end{array}$ & $\begin{array}{l}1.08 \\
1.43\end{array}$ & $\begin{array}{l}0.95 \\
1.28\end{array}$ & $\frac{1.1 .22}{1.36}$ & \begin{tabular}{|l}
1.04 \\
1.39
\end{tabular} & \begin{tabular}{l|l} 
& 1.0 \\
& 1.3
\end{tabular} & .1.1.27 & $\frac{1.1 .22}{1.36}$ & \begin{tabular}{|l}
1.02 \\
1.37
\end{tabular} & \begin{tabular}{|l|l}
1.36 \\
1.72
\end{tabular} & \begin{tabular}{|l|l}
1.36 \\
1.73
\end{tabular} & $\frac{11.67}{11.91}$ & $\begin{array}{r}11.68 \\
11.91\end{array}$ & $\begin{array}{l}11.67 \\
11.91 \\
\end{array}$ & $\begin{array}{l}0.933 \\
.26\end{array}$ & $\frac{1.03}{1.38}$ & $\begin{array}{l}0.14 \\
0.74\end{array}$ & $\frac{0.11}{0.72}$ & $\frac{0.82}{1.27}$ & $\frac{1.35}{1.71}$ & $\begin{array}{l}1.34 \\
1.69\end{array}$ & \begin{tabular}{|l|l|l|l|}
14.25 \\
\end{tabular} & \begin{tabular}{|l}
0.55 \\
0.89 \\
\end{tabular} & \begin{tabular}{|l}
0.98 \\
0.9
\end{tabular} & $\frac{1.15}{1.46}$ & \begin{tabular}{|l|l}
1.15 \\
1.46
\end{tabular} & $\begin{array}{l}14.18 \\
1.23 \\
\end{array}$ & $\frac{14.41}{14.19}$ & $\frac{14.16}{14.25}$ & \begin{tabular}{|l|l|} 
& 0.72 \\
\end{tabular} & & & & & \\
\hline & $\frac{1.12}{5.52}$ & $\frac{1.12}{5.52}$ & $\begin{array}{l}0.98 \\
540\end{array}$ & $\begin{array}{l}1.08 \\
540\end{array}$ & $\frac{1.11}{5.51}$ & & 1.09 & $\begin{array}{l}1.08 \\
59\end{array}$ & \begin{tabular}{|l|l|}
1.09 \\
5.49
\end{tabular} & \begin{tabular}{|l|l|}
1.41 \\
5.59
\end{tabular} & $\begin{array}{l}\frac{1.42}{559} \\
5\end{array}$ & $\begin{array}{l}11.70 \\
11.60\end{array}$ & $\begin{array}{ll}11.7 \\
11.61\end{array}$ & $\begin{array}{l}11.70 \\
11.60\end{array}$ & $\begin{array}{l}0.96 \\
538\end{array}$ & $\begin{array}{ll}1.07 \\
547\end{array}$ & $\begin{array}{l}0.34 \\
5.8\end{array}$ & \begin{tabular}{|l|l|}
0.31 \\
5.17
\end{tabular} & \begin{tabular}{|l|l|}
5.89 \\
5.37
\end{tabular} & $\begin{array}{l}1.40 \\
5.60\end{array}$ & $\begin{array}{l}1.39 \\
566\end{array}$ & $\frac{14.11}{1.14}$ & $\frac{0.58}{489}$ & \begin{tabular}{|l|l|}
0.82 \\
5.62
\end{tabular} & $\begin{array}{l}1.16 \\
544\end{array}$ & $\frac{1.16}{5.41}$ & $\begin{array}{l}14.16 \\
153\end{array}$ & $\begin{array}{l}14.10 \\
15323\end{array}$ & $\begin{array}{l}14,1 \\
1.3 .3\end{array}$ & $\begin{array}{l}0.3 \\
5.5\end{array}$ & $\frac{0.56}{54}$ & & & & \\
\hline$\frac{1452}{4452}$ & 33 & 533 & $\frac{5.40}{5.21}$ & $\frac{1.46}{5.26}$ & $\frac{5.31}{5.29}$ & & . & $\frac{5.47}{5.26}$ & \begin{tabular}{|l|l|}
5.27 \\
\end{tabular} & \begin{tabular}{|l|l|l|}
537 \\
\end{tabular} & 5.38 & $\frac{11.50}{11.50}$ & $\frac{11.01}{11.51}$ & $\frac{1.50}{11.50}$ & 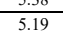 & 5.428 & 5.01 & $\frac{3.10}{5.00}$ & $\frac{.3 .19}{05.19}$ & $\frac{.007}{5.37}$ & $\frac{1.00}{5.37}$ & $\frac{154}{1527}$ & \begin{tabular}{|l|}
4.59 \\
469
\end{tabular} & $\begin{array}{l}5.03 \\
5.43\end{array}$ & $\frac{514}{5.22}$ & $\frac{5.41}{5-22}$ & $\frac{1.3}{157}$ & $\frac{15303}{15.19}$ & $\frac{1.3 .3}{151}$ & \begin{tabular}{|l|}
5.1 \\
494
\end{tabular} & $\frac{3.44}{566}$ & & 03. & & \\
\hline & 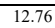 & 2.74 & 12.68 & 12.78 & 12.81 & 12.2. & 2.79 & $\begin{array}{ll}12.78 \\
\end{array}$ & 12.79 & \begin{tabular}{|l|l|}
12.91 \\
\end{tabular} & 12.92 & 4.57 & $\begin{array}{l}4.58 \\
\end{array}$ & 4.57 & $\begin{array}{l}12.68 \\
\end{array}$ & 12.70 & $\begin{array}{l}22,61 \\
\end{array}$ & $\begin{array}{l}12.59 \\
\end{array}$ & 12.7 & 12.92 & 12.92 & & $\overline{12.41}$ & & & & $\begin{array}{l}15.19 \\
\end{array}$ & 15.01 & & 1253 & & & & & \\
\hline & 2.3. & 2.911 & 12.84 & 12.86 & 12.89 & & & $\begin{array}{l}12.86 \\
\end{array}$ & 12.87 & 13.0 & $\begin{array}{ll}13.01 \\
\end{array}$ & 4.43 & $\begin{array}{l}4.44 \\
\end{array}$ & \begin{tabular}{|l|l}
4.43 \\
\end{tabular} & \begin{tabular}{ll|l}
12.84 \\
\end{tabular} & 12.87 & 12.76 & 12.74 & $\begin{array}{l}12.84 \\
\end{array}$ & $\begin{array}{l}13.01 \\
\end{array}$ & 13.02 & 15.27 & 12.52 & 12.98 & $\frac{12.85}{125}$ & $\frac{12.85}{105}$ & & & & & & & & & \\
\hline
\end{tabular}


4 Table 3: Estimation of mean inter-populational evolutionary diversity per site among sub-genotypes of genotype VI Avian avulavirus 1 using partial sequences of $F$ gene. The genetic distance of viruses from Pakistan origin is bold

\begin{tabular}{|c|c|c|c|c|c|c|c|c|c|c|c|c|c|c|}
\hline Sub-genotype & VIa & VIb & VIc & VId & VIe & VIf & VIg & VIh & VIi & VIj & VIk & VII & VIm & VIn \\
\hline \multicolumn{15}{|l|}{ VIa $(n=2)$} \\
\hline VIb $(n=3)$ & 0.099 & & & & & & & & & & & & & \\
\hline VIc $(n=3)$ & 0.101 & 0.096 & & & & & & & & & & & & \\
\hline VId $(n=2)$ & 0.114 & 0.118 & 0.104 & & & & & & & & & & & \\
\hline VIe $(n=5)$ & 0.080 & 0.088 & 0.093 & 0.110 & & & & & & & & & & \\
\hline VIf $(n=4)$ & 0.088 & 0.094 & 0.104 & 0.124 & 0.067 & & & & & & & & & \\
\hline VIg $(n=5)$ & 0.103 & 0.098 & 0.084 & 0.091 & 0.101 & 0.106 & & & & & & & & \\
\hline VIh $(n=3)$ & 0.092 & 0.105 & 0.117 & 0.139 & 0.092 & 0.101 & 0.113 & & & & & & & \\
\hline VIi $(n=3)$ & 0.129 & 0.127 & 0.116 & 0.024 & 0.122 & 0.136 & 0.099 & 0.148 & & & & & & \\
\hline $\mathbf{V I j}(n=2)$ & 0.121 & 0.128 & 0.106 & 0.119 & 0.106 & 0.117 & 0.096 & 0.134 & 0.122 & & & & & \\
\hline VIk $(n=3)$ & 0.012 & 0.096 & 0.097 & 0.111 & 0.075 & 0.082 & 0.100 & 0.084 & 0.126 & 0.120 & & & & \\
\hline VII $(n=2)$ & 0.047 & 0.094 & 0.093 & 0.114 & 0.073 & 0.084 & 0.099 & 0.080 & 0.126 & 0.114 & 0.040 & & & \\
\hline $\operatorname{VIm}(n=6)$ & 0.114 & 0.119 & 0.106 & 0.106 & 0.116 & 0.110 & 0.077 & 0.119 & 0.117 & 0.089 & 0.113 & 0.112 & & \\
\hline VIn $(n=5)$ & 0.057 & 0.093 & 0.097 & 0.116 & 0.0772 & 0.084 & 0.089 & 0.078 & 0.124 & 0.117 & 0.053 & 0.051 & 0.116 & \\
\hline
\end{tabular}


Table 4: Estimation of mean inter-populational evolutionary diversity per site among sub-genotypes of genotype VII Avian avulavirus 1 using partial sequences of $F$ gene. The genetic distance of viruses from Pakistan origin is bold

\begin{tabular}{|c|c|c|c|c|c|c|c|c|c|c|c|}
\hline Sub-genotype & VIIa & VIIb & VIIc & VIId & VIIe & VIIf & VIIg & VIIh & VIIi & VIIj & VIIk \\
\hline VIIa $(n=2)$ & & & & & & & & & & & \\
\hline VIIb $(n=7)$ & $\mathbf{0 . 2 5 1}$ & & & & & & & & & & \\
\hline VIIc $(n=3)$ & 0.300 & 0.187 & & & & & & & & & \\
\hline VIId $(\mathrm{n}=3)$ & 0.176 & 0.147 & 0.231 & & & & & & & & \\
\hline VIIe $(\mathrm{n}=6)$ & $\mathbf{0 . 4 0 1}$ & $\mathbf{0 . 3 0 6}$ & 0.312 & 0.296 & & & & & & & \\
\hline VIIf $(\mathrm{n}=8)$ & $\mathbf{0 . 2 1 5}$ & $\mathbf{0 . 0 1 9}$ & 0.231 & 0.160 & $\mathbf{0 . 3 3 9}$ & & & & & & \\
\hline VIIg $(\mathrm{n}=4)$ & 0.407 & 0.306 & 0.317 & 0.301 & 0.002 & 0.345 & & & & & \\
\hline VIIh $(\mathrm{n}=4)$ & 0.187 & 0.172 & 0.255 & 0.127 & 0.367 & 0.175 & 0.373 & & & & \\
\hline VIII $(\mathrm{n}=8)$ & $\mathbf{0 . 0 6 8}$ & $\mathbf{0 . 1 5 2}$ & 0.244 & 0.114 & $\mathbf{0 . 3 5 4}$ & $\mathbf{0 . 1 6 2}$ & 0.360 & 0.136 & & & \\
\hline VIIj $(\mathrm{n}=4)$ & 0.199 & 0.213 & 0.278 & 0.074 & 0.343 & 0.209 & 0.349 & 0.169 & 0.148 & & \\
\hline VIIk $(\mathrm{n}=3)$ & 0.186 & 0.212 & 0.263 & 0.133 & 0.342 & 0.192 & 0.348 & 0.149 & 0.135 & 0.137 & \\
\hline
\end{tabular}

Table 5: Estimation of mean inter-populational evolutionary diversity per site among sub-genotypes of genotype XIII Avian avulavirus 1 using partial sequences of $F$ gene. The genetic distance of viruses from Pakistan origin is bold

\begin{tabular}{|c|c|c|c|c|}
\hline Sub-genotype & XIIIa & XIIIb & XIIIc & XIIId \\
\hline XIIIa $(\mathrm{n}=4)$ & & & & \\
\hline XIIIb $(\mathrm{n}=4)$ & 0.057 & & & \\
\hline XIIIc $(\mathrm{n}=3)$ & 0.068 & 0.079 & & \\
\hline XIIId $(\mathrm{n}=3)$ & 0.045 & $\mathbf{0 . 0 3 9}$ & 0.098 & \\
\hline
\end{tabular}


17 Table 6: Comparative residue analysis of all coding genes of so-far reported Avian avulavirus 1 from Pakistan

\begin{tabular}{|c|c|c|c|}
\hline Proteins & Conserved and Functional Motifs & Genotype & Comparative residue substitutions \\
\hline \multirow{3}{*}{ NP } & \multirow{3}{*}{ N-N self-assembly motif ( $\left(322\right.$ FAPAEYAQLYSFAMG $\left.{ }^{336}\right)$} & VI & ${ }^{21} \mathrm{~A},{ }^{110} \mathrm{~N},{ }^{142} \mathrm{~S},{ }^{146} \mathrm{I},{ }^{203} \mathrm{~V},{ }^{288} \mathrm{~T},{ }^{341} \mathrm{I},{ }^{406} \mathrm{~V},{ }^{421} \mathrm{~N},{ }^{464} \mathrm{~S},{ }^{480} \mathrm{~T}$ \\
\hline & & VII & ${ }^{21} \mathrm{~T},{ }^{110} \mathrm{~S},{ }^{142} \mathrm{G},{ }^{146} \mathrm{~V},{ }^{203} \mathrm{I},{ }^{288} \mathrm{~A},{ }^{341} \mathrm{~L},{ }^{406} \mathrm{M},{ }^{421} \mathrm{D},{ }^{464} \mathrm{P},{ }^{480} \mathrm{~S}$ \\
\hline & & XIII & ${ }^{21} \mathrm{~T},{ }^{110} \mathrm{~N},{ }^{142} \mathrm{G},{ }^{146} \mathrm{~V},{ }^{203} \mathrm{~V},{ }^{288} \mathrm{~T},{ }^{341} \mathrm{~L},{ }^{406} \mathrm{M},{ }^{421} \mathrm{D},{ }^{464} \mathrm{P},{ }^{480} \mathrm{~S}$ \\
\hline \multirow{3}{*}{$\mathrm{P}$} & \multirow{3}{*}{ RNA editing motif (GGGAAAAA) } & VI & ${ }^{10} \mathrm{E},{ }^{66} \mathrm{~S},{ }^{67} \mathrm{E},{ }^{83} \mathrm{I},{ }^{90} \mathrm{~T},{ }^{103} \mathrm{G},{ }^{126} \mathrm{~S},{ }^{138} \mathrm{~S},{ }^{146} \mathrm{P},{ }^{159} \mathrm{~N},{ }^{163} \mathrm{R},{ }^{209} \mathrm{~S},{ }^{258} \mathrm{I},{ }^{323} \mathrm{~T},{ }^{333} \mathrm{~N},{ }^{343} \mathrm{I}$ \\
\hline & & VII & ${ }^{10} \mathrm{D},{ }^{66} \mathrm{P},{ }^{67} \mathrm{D},{ }^{83} \mathrm{~A},{ }^{90} \mathrm{~A},{ }^{103} \mathrm{E},{ }^{126} \mathrm{~N},{ }^{138} \mathrm{G},{ }^{146} \mathrm{Q},{ }^{159} \mathrm{~S},{ }^{163} \mathrm{E},{ }^{209} \mathrm{~N},{ }^{258} \mathrm{M},{ }^{323} \mathrm{~A},{ }^{333} \mathrm{H},{ }^{343} \mathrm{~A}$ \\
\hline & & XIII & ${ }^{10} \mathrm{D},{ }^{66} \mathrm{P},{ }^{67} \mathrm{D},{ }^{83} \mathrm{~A},{ }^{90} \mathrm{~A},{ }^{103} \mathrm{E},{ }^{126} \mathrm{~N},{ }^{138} \mathrm{G},{ }^{146} \mathrm{Q},{ }^{159} \mathrm{~S},{ }^{163} \mathrm{E},{ }^{209} \mathrm{~N},{ }^{258} \mathrm{M},{ }^{323} \mathrm{~A},{ }^{333} \mathrm{H},{ }^{343} \mathrm{~A}$ \\
\hline \multirow{3}{*}{ M } & \multirow{3}{*}{$\begin{array}{l}\text { M late domain }\left({ }^{23} \mathrm{FPIV}^{26}\right) \text {, Bipartite nuclear localization motif } \\
\left.\qquad{ }^{(24} \mathrm{KKGKKVTFDKIEEKIRR}^{263}\right)\end{array}$} & VI & ${ }^{36} \mathrm{~K},{ }^{53} \mathrm{~K},{ }^{75} \mathrm{~V},{ }^{77} \mathrm{M},{ }^{105} \mathrm{~K},{ }^{136} \mathrm{Q},{ }^{142} \mathrm{~T},{ }^{143} \mathrm{~A},{ }^{196} \mathrm{I},{ }^{213} \mathrm{E},{ }^{353} \mathrm{R},{ }^{555} \mathrm{~T},{ }^{363} \mathrm{R}$ \\
\hline & & VII & ${ }^{36} \mathrm{Q},{ }^{53} \mathrm{R},{ }^{75} \mathrm{~A},{ }^{77} \mathrm{~V},{ }^{105} \mathrm{E},{ }^{136} \mathrm{R},{ }^{142} \mathrm{M},{ }^{143} \mathrm{~V},{ }^{196} \mathrm{~V},{ }^{213} \mathrm{D},{ }^{353} \mathrm{~K},{ }^{355} \mathrm{~A},{ }^{363} \mathrm{~K}$ \\
\hline & & XIII & ${ }^{36} \mathrm{Q},{ }^{53} \mathrm{~K},{ }^{75} \mathrm{~V},{ }^{77} \mathrm{~V},{ }^{105} \mathrm{E},{ }^{136} \mathrm{R},{ }^{142} \mathrm{M},{ }^{143} \mathrm{~V},{ }^{196} \mathrm{~V},{ }^{213} \mathrm{E},{ }^{353} \mathrm{R},{ }^{355} \mathrm{~T},{ }^{363} \mathrm{R}$ \\
\hline \multirow{3}{*}{$\mathrm{F}$} & \multirow{3}{*}{$\begin{array}{c}\text { Single peptide }\left({ }^{1} \text { MGSKPSIRIPVPLMLITRI }{ }^{19}\right) \text {, Cleavage motif } \\
\left({ }^{112} \mathrm{RRQK}^{1} / \mathrm{RR}^{117}\right) \text {, Fusion peptide } \\
\left({ }^{1{ }^{117}} \text { FIGAVIGSIVALGVATAAQITAAAALI }{ }^{142}\right)\end{array}$} & VI & $\begin{array}{l}{ }^{14} \mathrm{~S},{ }^{25} \mathrm{C},{ }^{90} \mathrm{~N},{ }^{107} \mathrm{~S},{ }^{121} \mathrm{I},{ }^{124} \mathrm{G},{ }^{132} \mathrm{~S},{ }^{176} \mathrm{~A},{ }^{179} \mathrm{I},{ }^{208} \mathrm{I},{ }^{246} \mathrm{I},{ }^{255} \mathrm{I},{ }^{270} \mathrm{~A},{ }^{272} \mathrm{H},{ }^{304} \mathrm{G},{ }^{321} \mathrm{R},{ }^{342} \mathrm{~N}, \\
{ }^{337} \mathrm{H},{ }^{385} \mathrm{~A},{ }^{402} \mathrm{~V},{ }^{411} \mathrm{H},{ }^{425} \mathrm{~S},{ }^{445} \mathrm{Q},{ }^{448} \mathrm{~V},{ }^{452} \mathrm{E},{ }^{487} \mathrm{R},{ }^{492} \mathrm{D},{ }^{494} \mathrm{~K},{ }^{506} \mathrm{~V},{ }^{009} \mathrm{~A},{ }^{522} \mathrm{~S},{ }^{537} \mathrm{M}\end{array}$ \\
\hline & & VII & 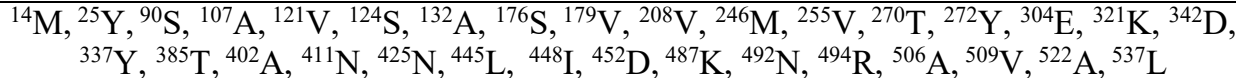 \\
\hline & & XIII & $\begin{array}{c}{ }^{14} \mathrm{~S},{ }^{25} \mathrm{C},{ }^{, 0} \mathrm{~S}{ }^{107} \mathrm{~S},{ }^{121} \mathrm{~V},{ }^{124} \mathrm{~S},{ }^{132} \mathrm{~A},{ }^{176} \mathrm{~A},{ }^{179} \mathrm{~V},{ }^{208} \mathrm{~V},{ }^{246} \mathrm{M},{ }^{, 255} \mathrm{~V},{ }^{, 70} \mathrm{~A}{ }^{, 27} \mathrm{Y},{ }^{304} \mathrm{E},{ }^{321} \mathrm{~K},{ }^{342} \mathrm{~N}, \\
{ }^{337} \mathrm{Y},{ }^{385} \mathrm{~A},{ }^{402} \mathrm{~A},{ }^{411} \mathrm{~N},{ }^{225} \mathrm{~S},{ }^{445} \mathrm{Q},{ }^{448} \mathrm{I},{ }^{452} \mathrm{E},{ }^{487} \mathrm{~K},{ }^{492} \mathrm{~N},{ }^{494} \mathrm{R},{ }^{506} \mathrm{~V},{ }^{509} \mathrm{~A},{ }^{522} \mathrm{~S},{ }^{537} \mathrm{~L}\end{array}$ \\
\hline \multirow{3}{*}{$\mathrm{HN}$} & \multirow{3}{*}{$\begin{array}{c}\text { Hydrophobic signal anchor }\left({ }^{25} \text { FRIAVLLLMIMILAISAAAL }{ }^{44}\right) \text {, Hexapeptide } \\
\text { motif }\left({ }^{234} \mathrm{NRKSCS}^{239}\right) \text {, Haemagglutinin active motif-I }\left({ }^{314} \mathrm{FPVYGGL}^{320}\right) \\
\text { Haemagglutinin active motif-II }\left({ }^{399} \mathrm{GAEGRI}^{204}\right)\end{array}$} & VI & $\begin{array}{r}{ }^{2} \mathrm{D},{ }^{6} \mathrm{R},{ }^{7} \mathrm{~K},{ }^{9} \mathrm{~V},{ }^{27} \mathrm{~V},{ }^{36} \mathrm{~T},{ }^{39} \mathrm{~F},{ }^{46} \mathrm{H},{ }^{56} \mathrm{I},{ }^{57} \mathrm{~A},{ }^{62} \mathrm{M},{ }^{65} \mathrm{R},{ }^{75} \mathrm{~N},{ }^{102} \mathrm{M},{ }^{112} \mathrm{H},{ }^{182} \mathrm{~A},{ }^{323} \mathrm{~A},{ }^{218} \mathrm{R},{ }^{263} \mathrm{R}, \mathrm{R},{ }^{289} \mathrm{~A}, \\
{ }^{353} \mathrm{Q},{ }^{390} \mathrm{~V},{ }^{395} \mathrm{~V},{ }^{431} \mathrm{~V},{ }^{495} \mathrm{E}\end{array}$ \\
\hline & & VII & 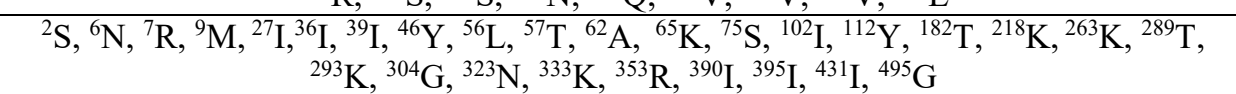 \\
\hline & & XIII & 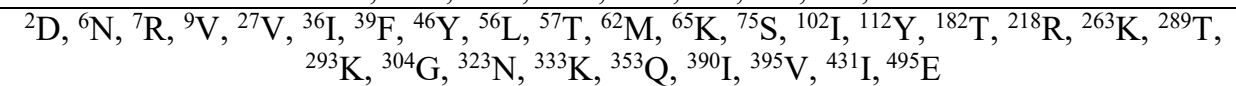 \\
\hline \multirow{3}{*}{$\mathrm{L}$} & \multirow{3}{*}{ 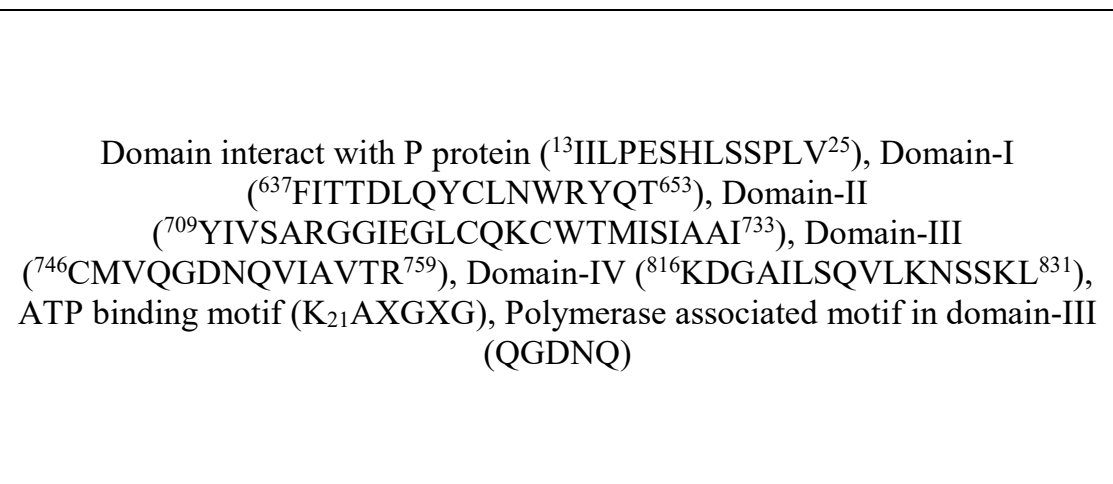 } & VI & $\begin{array}{l}{ }^{12} \mathrm{Q},{ }^{46} \mathrm{I},{ }^{99} \mathrm{~S},{ }^{103} \mathrm{~V},{ }^{122} \mathrm{~A},{ }^{149} \mathrm{~L}, \\
{ }^{155} \mathrm{~N},\end{array}$ \\
\hline & & VII & 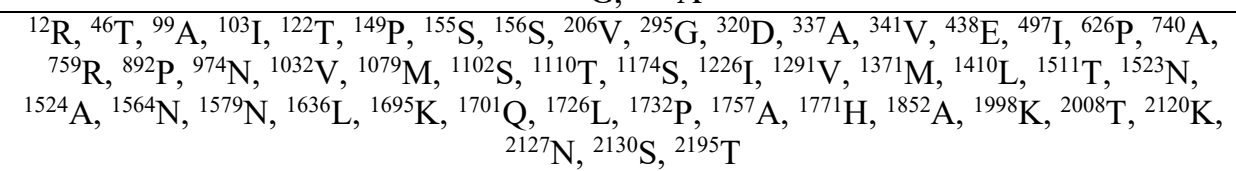 \\
\hline & & XIII & $\begin{array}{l}{ }^{12} \mathrm{Q},{ }^{46} \mathrm{~T},{ }^{99} \mathrm{~A},{ }^{103} \mathrm{~V},{ }^{122} \mathrm{~T},{ }^{149} \mathrm{P},{ }^{155} \mathrm{~S},{ }^{156} \mathrm{~S},{ }^{206} \mathrm{~V},{ }^{295} \mathrm{G},{ }^{320} \mathrm{D},{ }^{337} \mathrm{~A},{ }^{341} \mathrm{~V},{ }^{438} \mathrm{D},{ }^{497} \mathrm{~V},{ }^{226} \mathrm{P},{ }^{740} \mathrm{~S}, \\
{ }^{759} \mathrm{R},{ }^{892} \mathrm{P},,{ }^{974} \mathrm{~N},{ }^{1032} \mathrm{~V},{ }^{1079} \mathrm{M},{ }^{1102} \mathrm{~S},{ }^{1110} \mathrm{~N},{ }^{1174} \mathrm{~S},{ }^{1226} \mathrm{I},{ }^{1291} \mathrm{I},{ }^{1371} \mathrm{M},{ }^{1410} \mathrm{~L},{ }^{1511} \mathrm{~T},{ }^{1523} \mathrm{~S},{ }^{1524} \mathrm{~A},\end{array}$ \\
\hline
\end{tabular}


19 Table 7: Comparative residue analysis of all sub-genotypes of Avian avulavirus 1 with respect of field used vaccine strains (LaSota; AF077761 20 and Mukteshwar; EF201805)

\begin{tabular}{|c|c|c|c|c|c|c|c|c|c|c|c|c|c|c|c|c|c|c|c|c|c|c|c|c|}
\hline \multirow{2}{*}{ Genotype } & \multirow{2}{*}{ Representative isolates } & \multicolumn{23}{|c|}{ Amino acid position and substitutions } \\
\hline & & 12 & 16 & 27 & 31 & 33 & 35 & 38 & 40 & 43 & 46 & 47 & 48 & 50 & 54 & 65 & 68 & 71 & $76-81$ & 85 & 88 & 89 & 96 & 109 \\
\hline II & Vaccine strain (AF077761) & $\mathrm{K}$ & $\mathrm{I}$ & $\mathrm{V}$ & $\mathrm{P}$ & $\mathrm{L}$ & $\mathrm{K}$ & $\mathrm{E}$ & $\mathrm{C}$ & $\mathrm{A}$ & $\mathrm{D}$ & A & $\mathrm{Y}$ & $\mathrm{R}$ & $\mathrm{T}$ & $\mathrm{R}$ & $\mathrm{E}$ & $\mathrm{T}$ & GRQGRL & $\mathrm{I}$ & $\mathrm{G}$ & $\mathrm{V}$ & $\mathrm{A}$ & $\mathrm{K}$ \\
\hline III & Vaccine strain (EF201805) & - & - & - & - & $\mathrm{M}$ & - & - & - & - & $\mathrm{E}$ & - & - & - & - & - & - & - & R--R-F & - & $\mathrm{S}$ & - & - & $\mathrm{N}$ \\
\hline \multirow{2}{*}{ VI } & VIg & - & - & I & - & $\mathrm{M}$ & - & - & - & - & $\mathrm{E}$ & - & - & - & $\mathrm{A}$ & - & $\mathrm{G}$ & $\mathrm{S}$ & R-KK-F & - & $\mathrm{S}$ & - & $\mathrm{S}$ & $\mathrm{N}$ \\
\hline & VIm & - & - & - & - & $\mathrm{M}$ & - & - & - & - & $\mathrm{E}$ & - & - & - & - & - & $\mathrm{G}$ & $\mathrm{S}$ & R--K-F & - & - & - & $\mathrm{S}$ & $\mathrm{N}$ \\
\hline \multirow{4}{*}{ VII } & VIIa & - & - & - & - & $\mathrm{M}$ & - & $\mathrm{G}$ & - & $\mathrm{P}$ & $\mathrm{E}$ & $\mathrm{G}$ & $\mathrm{C}$ & $\mathrm{S}$ & $\mathrm{P}$ & $\mathrm{K}$ & $\mathrm{G}$ & $\mathrm{A}$ & R--K-F & $\mathrm{V}$ & $\mathrm{S}$ & - & - & $\mathrm{N}$ \\
\hline & VIIb & - & $\mathrm{V}$ & - & $\mathrm{L}$ & $\mathrm{M}$ & $\mathrm{R}$ & - & - & - & $\mathrm{E}$ & - & - & - & - & $\mathrm{K}$ & $\mathrm{G}$ & $\mathrm{S}$ & R--K-F & $\mathrm{V}$ & $\mathrm{S}$ & - & - & $\mathrm{N}$ \\
\hline & VIIf & $\mathrm{R}$ & - & - & - & $\mathrm{M}$ & - & - & - & - & $\mathrm{E}$ & - & - & - & - & - & $\mathrm{G}$ & $\mathrm{S}$ & R--K-F & $\mathrm{V}$ & $\mathrm{S}$ & - & - & $\mathrm{N}$ \\
\hline & VIIi & - & $\mathrm{V}$ & - & - & $\mathrm{M}$ & - & - & - & - & $\mathrm{E}$ & - & - & - & - & $\mathrm{K}$ & $\mathrm{G}$ & $\mathrm{A}$ & R--K-F & $\mathrm{V}$ & $\mathrm{S}$ & I & - & $\mathrm{N}$ \\
\hline \multirow{2}{*}{ XIII } & XIIIb & - & - & - & - & $\mathrm{M}$ & - & $\mathrm{K} / \mathrm{Q}$ & $\mathrm{G}$ & - & $E$ & - & - & - & - & - & $G$ & $\mathrm{~S}$ & R--K-F & $\mathrm{V}$ & $\mathrm{S}$ & - & - & $\mathrm{N}$ \\
\hline & XIIId & - & - & - & - & $\mathrm{M}$ & - & - & - & - & $\mathrm{E}$ & - & - & - & - & - & $\mathrm{G}$ & $\mathrm{A}$ & R--K-F & $\mathrm{V}$ & $\mathrm{S}$ & - & - & $\mathrm{N}$ \\
\hline
\end{tabular}

21 Note: The consensus sequences of each sub-genotype was constructed for comparative residue analysis against vaccine strain 
Table 8: Polymorphism results for nucleotide diversity of all coding genes (CDS analysis) of Avian avulavirus 1 belongs to different genotypes

\begin{tabular}{|c|c|c|c|c|c|c|c|c|c|c|c|c|c|c|c|c|c|c|}
\hline \multirow{2}{*}{ Parameters } & \multicolumn{6}{|c|}{ G-VI } & \multicolumn{6}{|c|}{ G-VII } & \multicolumn{6}{|c|}{ G-XIII } \\
\hline & NP & $\mathrm{P}$ & $\mathrm{M}$ & $\mathrm{F}$ & $\mathrm{HN}$ & $\mathrm{L}$ & NP & $\mathrm{P}$ & $\mathrm{M}$ & $\mathrm{F}$ & $\mathrm{HN}$ & $\mathrm{L}$ & NP & $\mathrm{P}$ & $\mathrm{M}$ & $\mathrm{F}$ & $\mathrm{HN}$ & $\mathrm{L}$ \\
\hline Total no. of Mutation & 75 & 69 & 50 & 74 & 89 & 264 & 126 & 179 & 121 & 101 & 87 & 396 & 48 & 98 & 41 & 45 & 80 & 383 \\
\hline Total number of sites & 1470 & 1188 & 1095 & 1629 & 1715 & 6615 & 1470 & 1187 & 1095 & 1629 & 1714 & 6614 & 1470 & 1188 & 1095 & 1629 & 1715 & 6614 \\
\hline $\begin{array}{l}\text { Invariable Monomorphic } \\
\text { sites }\end{array}$ & 1396 & 1119 & 1045 & 1555 & 1626 & 6352 & 1346 & 1011 & 974 & 1528 & 1627 & 6229 & 1423 & 1090 & 1054 & 1584 & 1635 & 6233 \\
\hline Variable Polymorphic Sites & 74 & 69 & 50 & 74 & 89 & 263 & 124 & 176 & 121 & 101 & 87 & 385 & 47 & 98 & 41 & 45 & 80 & 381 \\
\hline Singleton Variable Sites & 69 & 69 & 48 & 71 & 81 & 246 & 15 & 9 & 7 & 26 & 18 & 90 & 33 & 0 & 25 & 1 & 66 & 226 \\
\hline Parsimony Informative Sites & 5 & 5 & 2 & 3 & 8 & 17 & 109 & 167 & 114 & 75 & 69 & 295 & 14 & 98 & 16 & 44 & 14 & 155 \\
\hline No. of Haplotypes (h) & 4 & 4 & 4 & 4 & 4 & 4 & 17 & 10 & 13 & 16 & 15 & 22 & 3 & 2 & 3 & 3 & 3 & 4 \\
\hline Nucleotide Diversity (Pi) & 0.02596 & 0.02974 & 0.02314 & 0.02302 & 0.02672 & 0.02036 & 0.01511 & 0.02479 & 0.02043 & 0.01440 & 0.01178 & 0.01210 & 0.01490 & 0.04949 & 0.01790 & 0.01645 & 0.02029 & 0.02782 \\
\hline $\begin{array}{l}\text { Average no. of pairwise } \\
\text { nucleotide difference }(\mathrm{k})\end{array}$ & 38.167 & 35.333 & 25.333 & 37.500 & 45.833 & 134.667 & 22.212 & 29.422 & 22.372 & 23.458 & 20.185 & 80.025 & 21.900 & 58.800 & 19.600 & 26.800 & 34.800 & 184.000 \\
\hline Tajima' D & -0.7001 & -0.6387 & -0.7401 & -0.7409 & -0.5841 & -0.6803 & -1.2868 & -1.4740 & -1.1567 & -0.4449 & -0.4470 & -0.9118 & -0.3732 & $1.8997^{*}$ & -0.0306 & $1.8139^{*}$ & -0.7112 & 0.0066 \\
\hline
\end{tabular}

24 Note: The intraspecific polymorphism divergence time for whole genome sequences was estimated as T=1.856 for genotype VI, T=4.944* for

25 genotype VII and T=2.245 for genotype XIII $(* 0.01<p<0.05, * * 0.001<p<0.01$, *** $p<0.001)$.

26 
27 Table 9: Estimation of synonymous and non-synonymous substitutions rate in coding genes of so-far reported Avian avulavirus 1 using LaSota 28 vaccine strain

\begin{tabular}{|c|c|c|c|c|c|c|c|c|c|c|c|c|c|c|c|c|c|c|}
\hline \multirow{2}{*}{ Parameters } & \multicolumn{6}{|c|}{ G-VI } & \multicolumn{6}{|c|}{ G-VII } & \multicolumn{6}{|c|}{ G-XIII } \\
\hline & $\mathrm{NP}$ & $P$ & $\mathrm{M}$ & $\mathrm{F}$ & $\mathrm{HN}$ & $\mathrm{L}$ & $\mathrm{NP}$ & $\mathrm{P}$ & $\mathrm{M}$ & $\mathrm{F}$ & $\mathrm{HN}$ & $\mathrm{L}$ & $\mathrm{NP}$ & $\mathrm{P}$ & $\mathrm{M}$ & $\mathrm{F}$ & $\mathrm{HN}$ & $\mathrm{L}$ \\
\hline ds & 1.0209 & 0.6064 & 0.0861 & 0.7914 & 0.6011 & 0.1686 & 0.9698 & 0.6089 & 0.1109 & 0.8022 & 0.6004 & 0.1647 & 0.8371 & 0.5373 & 0.0916 & 0.7766 & 0.5833 & 0.1405 \\
\hline $\mathrm{dn}$ & 0.0456 & 0.1106 & 0.1901 & 0.0577 & 0.1081 & 0.1559 & 0.0442 & 0.0920 & 0.2242 & 0.0568 & 0.1247 & 0.1591 & 0.0465 & 0.0840 & 0.2061 & 0.0527 & 0.1262 & 0.1500 \\
\hline $\mathrm{ds} / \mathrm{dn}$ & 22.3883 & 5.4842 & 0.4530 & 13.7208 & 5.5600 & 1.0814 & 21.9689 & 6.6048 & 0.4938 & 14.1531 & 4.8165 & 1.0352 & 17.9967 & 6.3635 & 0.4447 & 14.7523 & 4.6290 & 0.9340 \\
\hline Variance $(\mathrm{ds})$ & 0.016500 & 0.005286 & 0.000393 & 0.006032 & 0.003413 & 0.000143 & 0.014460 & 0.005442 & 0.000499 & 0.007238 & 0.003817 & 0.000138 & 0.009550 & 0.003647 & 0.000435 & 0.006409 & 0.003383 & 0.000104 \\
\hline Std Deviation (ds) & 0.128453 & 0.072704 & 0.019826 & 0.077667 & 0.058420 & 0.011972 & 0.120248 & 0.073770 & 0.022339 & 0.085076 & 0.061779 & 0.011733 & 0.097723 & 0.060388 & 0.020851 & 0.080055 & 0.058167 & 0.010219 \\
\hline Variance (dn) & 0.000646 & 0.000496 & 0.000166 & 0.000356 & 0.000340 & 0.000031 & 0.000495 & 0.000435 & 0.000193 & 0.000359 & 0.000390 & 0.000031 & 0.000389 & 0.000315 & 0.000163 & 0.000330 & 0.000360 & 0.000028 \\
\hline Std Deviation (dn) & 0.025424 & 0.022262 & 0.012902 & 0.018877 & 0.018437 & 0.005587 & 0.022242 & 0.020863 & 0.013910 & 0.018960 & 0.019752 & 0.005585 & 0.019719 & 0.017744 & 0.012760 & 0.018162 & 0.018985 & 0.005291 \\
\hline $\mathrm{ps} / \mathrm{pn}$ & 12.6040 & 4.0435 & 0.4844 & 8.8034 & 4.1070 & 1.0726 & 12.6930 & 4.8061 & 0.5310 & 9.0242 & 3.5974 & 1.0311 & 11.1802 & 4.8101 & 0.4787 & 9.5153 & 3.4950 & 0.9383 \\
\hline Variance (ps) & 0.001080 & 0.001046 & 0.000312 & 0.000731 & 0.000687 & 0.000091 & 0.001089 & 0.001045 & 0.000372 & 0.000852 & 0.000769 & 0.000089 & 0.001024 & 0.000818 & 0.000341 & 0.000808 & 0.000714 & 0.000071 \\
\hline Std Deviation (ps) & 0.032867 & 0.032348 & 0.017677 & 0.027038 & 0.026210 & 0.009561 & 0.032998 & 0.032322 & 0.019274 & 0.029188 & 0.027739 & 0.009410 & 0.031999 & 0.028609 & 0.018453 & 0.028426 & 0.026720 & 0.008442 \\
\hline Variance (pn) & 0.000042 & 0.000098 & 0.000132 & 0.000043 & 0.000068 & 0.000020 & 0.000495 & 0.000083 & 0.000144 & 0.000042 & 0.000079 & 0.000020 & 0.000042 & 0.000070 & 0.000128 & 0.000042 & 0.000076 & 0.000019 \\
\hline Std Deviation (pn) & 0.006506 & 0.009908 & 0.011503 & 0.006561 & 0.008272 & 0.004462 & 0.022242 & 0.009114 & 0.012005 & 0.006503 & 0.008869 & 0.004482 & 0.006451 & 0.008346 & 0.011293 & 0.006447 & 0.008722 & 0.004380 \\
\hline
\end{tabular}

29 Abbreviations: ds = synonymous substitutions per synonymous site, $\mathrm{dn}=$ non-synonymous substitutions per non- synonymous site, $\mathrm{ds} / \mathrm{dn}=$

30 proportion of ds and dn differences, $\mathrm{ps} / \mathrm{pn}=$ proportion of synonymous (ps) and non-synonymous (pn) differences

31 Table 10: Estimation of synonymous and non-synonymous substitutions rate in coding genes of so far reported Avian avulavirus 1 using

32 Mukstewar vaccine strain

\begin{tabular}{|c|c|c|c|c|c|c|c|c|c|c|c|c|c|c|c|c|c|c|}
\hline \multirow{2}{*}{ Parameters } & \multicolumn{6}{|c|}{ G-VI } & \multicolumn{6}{|c|}{ G-VII } & \multicolumn{6}{|c|}{ G-XIII } \\
\hline & $\mathrm{NP}$ & $\mathrm{P}$ & $\mathrm{M}$ & $\mathrm{F}$ & $\mathrm{HN}$ & $\mathrm{L}$ & $\mathrm{NP}$ & $\mathrm{P}$ & $\mathrm{M}$ & $\mathrm{F}$ & $\mathrm{HN}$ & $\mathrm{L}$ & $\mathrm{NP}$ & $\mathrm{P}$ & $\mathrm{M}$ & $\mathrm{F}$ & $\mathrm{HN}$ & $\mathrm{L}$ \\
\hline $\mathrm{ds}$ & 0.7490 & 0.4066 & 0.1050 & 0.6606 & 0.4617 & 0.1463 & 0.7929 & 0.5250 & 0.1034 & 0.6290 & 0.4396 & 0.1391 & 0.6755 & 0.4534 & 0.1007 & 0.6775 & 0.4558 & 0.1365 \\
\hline $\mathrm{dn}$ & 0.0286 & 0.1056 & 0.1460 & 0.0482 & 0.0872 & 0.1268 & 0.0278 & 0.0863 & 0.1788 & 0.0409 & 0.1011 & 0.1314 & 0.0360 & 0.0911 & 0.1612 & 0.0415 & 0.1034 & 0.1329 \\
\hline $\mathrm{ds} / \mathrm{dn}$ & 26.2265 & 3.8508 & 0.7199 & 13.7010 & 5.3007 & 1.1538 & 28.6792 & 6.0923 & 0.5770 & 15.4478 & 4.3496 & 1.0595 & 18.7682 & 4.9767 & 0.6253 & 16.3237 & 4.4137 & 1.0268 \\
\hline Variance $(\mathrm{ds})$ & 0.006991 & 0.002514 & 0.000494 & 0.004296 & 0.002105 & 0.000123 & 0.008341 & 0.004186 & 0.000466 & 0.004134 & 0.002024 & 0.000115 & 0.005695 & 0.002768 & 0.000483 & 0.004772 & 0.002107 & 0.000102 \\
\hline Std Deviation (ds) & 0.083615 & 0.050140 & 0.022221 & 0.065545 & 0.045885 & 0.011097 & 0.091331 & 0.064696 & 0.021592 & 0.064298 & 0.044984 & 0.010702 & 0.075465 & 0.052607 & 0.021988 & 0.069080 & 0.045906 & 0.010102 \\
\hline Variance $(\mathrm{dn})$ & 0.000172 & 0.000293 & 0.000145 & 0.000213 & 0.000193 & 0.000025 & 0.000200 & 0.000339 & 0.000166 & 0.000168 & 0.000210 & 0.000026 & 0.000205 & 0.000288 & 0.000149 & 0.000210 & 0.000216 & 0.000025 \\
\hline Std Deviation (dn) & 0.013117 & 0.017110 & 0.012056 & 0.014591 & 0.013907 & 0.005020 & 0.014140 & 0.018410 & 0.012874 & 0.012981 & 0.014504 & 0.005108 & 0.014333 & 0.016980 & 0.012217 & 0.014490 & 0.014694 & 0.004992 \\
\hline $\mathrm{ps} / \mathrm{pn}$ & 16.9039 & 3.1866 & 0.7392 & 9.4039 & 4.1915 & 1.1393 & 18.0230 & 4.6320 & 0.6057 & 10.7451 & 3.5178 & 1.0541 & 12.6676 & 3.9618 & 0.6502 & 11.0464 & 3.5407 & 1.0245 \\
\hline Variance (ps) & 0.000945 & 0.000850 & 0.000373 & 0.000738 & 0.000614 & 0.000083 & 0.001004 & 0.001021 & 0.000354 & 0.000772 & 0.000627 & 0.000079 & 0.000939 & 0.000820 & 0.000370 & 0.000783 & 0.000625 & 0.000071 \\
\hline Std Deviation (ps) & 0.030738 & 0.029159 & 0.019318 & 0.027162 & 0.024779 & 0.009129 & 0.031693 & 0.031950 & 0.018821 & 0.027793 & 0.025031 & 0.008890 & 0.030646 & 0.028633 & 0.019225 & 0.027985 & 0.025000 & 0.008420 \\
\hline Variance (pn) & 0.000023 & 0.000099 & 0.000110 & 0.000037 & 0.000056 & 0.000017 & 0.000024 & 0.000083 & 0.000126 & 0.000031 & 0.000065 & 0.000018 & 0.000034 & 0.000086 & 0.000114 & 0.000034 & 0.000064 & 0.000017 \\
\hline Std Deviation (pn) & 0.004819 & 0.009950 & 0.010481 & 0.006047 & 0.007512 & 0.004130 & 0.004910 & 0.009096 & 0.011224 & 0.005610 & 0.008071 & 0.004243 & 0.005821 & 0.009257 & 0.010681 & 0.005872 & 0.008002 & 0.004161 \\
\hline
\end{tabular}

33 Abbreviations: $d s=$ synonymous substitutions per synonymous site, $\mathrm{dn}=$ non-synonymous substitutions per non- synonymous site, $\mathrm{ds} / \mathrm{dn}=$

34 proportion of ds and dn differences, $\mathrm{ps} / \mathrm{pn}$ = proportion of synonymous (ps) and non-synonymous (pn) differences

35

36 
37 Table 11: A brief summary of the Datamonkey-derived natural pressure selection site/s analysis for individual complete genes (CDS) of so-far 38 reported Avian avulavirus 1

\begin{tabular}{|c|c|c|c|c|c|c|c|c|c|c|c|c|c|c|c|c|c|c|}
\hline \multirow{2}{*}{ Parameters } & \multicolumn{6}{|c|}{ G-VI } & \multicolumn{6}{|c|}{ G-VII } & \multicolumn{6}{|c|}{ G-XIII } \\
\hline & NP & $P$ & $\mathrm{M}$ & $F$ & $\mathrm{HN}$ & $\mathrm{L}$ & NP & $\mathrm{P}$ & $\mathrm{M}$ & $\mathrm{F}$ & $\mathrm{HN}$ & $\mathrm{L}$ & NP & $\mathrm{P}$ & $\mathrm{M}$ & $\mathrm{F}$ & $\mathrm{HN}$ & $\mathrm{L}$ \\
\hline Mean dN/dS & 0.050124 & 0.37830 & 0.01818 & 0.10890 & 0.24668 & 0.13024 & 0.09871 & 0.28340 & 0.01944 & 0.38894 & 0.29408 & 0.13761 & 0.09096 & 0.35729 & 0.16906 & 0.14771 & 0.16462 & 0.10332 \\
\hline \multicolumn{19}{|c|}{ Single Likelihood Ancestor Counting (SLAC) } \\
\hline $\begin{array}{l}\text { No. of positive } \\
\text { and negative } \\
\text { selection sites } \\
\text { along with } \\
\text { codon position }\end{array}$ & $\begin{array}{c}0 \text { positive } \\
\text { site and } 59 \\
\text { negative } \\
\text { sites }\end{array}$ & $\begin{array}{l}2 \text { positive } \\
\text { sites ( } 28, \\
147) \text { and } \\
33 \text { negative } \\
\text { sites }\end{array}$ & $\begin{array}{l}0 \text { positive } \\
\text { site and } \\
45 \\
\text { negative } \\
\text { sites }\end{array}$ & $\begin{array}{l}1 \text { positive } \\
\text { site }(179) \\
\text { and } 48 \\
\text { negative } \\
\text { sites }\end{array}$ & $\begin{array}{c}0 \text { positive } \\
\text { site and } 42 \\
\text { negative } \\
\text { sites }\end{array}$ & $\begin{array}{c}0 \text { positive } \\
\text { site and } \\
61 \\
\text { negative } \\
\text { sites }\end{array}$ & $\begin{array}{c}1 \\
\text { positive } \\
\text { site } \\
(124) \\
\text { and } 49 \\
\text { negative } \\
\text { sites } \\
\end{array}$ & $\begin{array}{c}0 \\
\text { positive } \\
\text { site and } \\
62 \\
\text { negative } \\
\text { sites }\end{array}$ & $\begin{array}{c}0 \\
\text { positive } \\
\text { site and } \\
51 \\
\text { negative } \\
\text { sites }\end{array}$ & $\begin{array}{c}2 \\
\text { positive } \\
\text { sites }(48, \\
342) \text { and } \\
64 \\
\text { negative } \\
\text { sites } \\
\end{array}$ & $\begin{array}{c}0 \\
\text { positive } \\
\text { site and } \\
48 \\
\text { negative } \\
\text { sites } \\
\end{array}$ & $\begin{array}{c}0 \\
\text { positive } \\
\text { site and } \\
109 \\
\text { negative } \\
\text { sites } \\
\end{array}$ & $\begin{array}{c}0 \\
\text { positive } \\
\text { site and } \\
43 \\
\text { negative } \\
\text { sites }\end{array}$ & $\begin{array}{c}0 \\
\text { positive } \\
\text { site and } \\
60 \\
\text { negative } \\
\text { sites } \\
\end{array}$ & $\begin{array}{c}0 \\
\text { positive } \\
\text { site and } \\
59 \\
\text { negative } \\
\text { sites }\end{array}$ & $\begin{array}{c}1 \\
\text { positive } \\
\text { site } \\
(202) \\
\text { and } 81 \\
\text { negative } \\
\text { sites } \\
\end{array}$ & $\begin{array}{c}0 \\
\text { positive } \\
\text { site and } \\
89 \\
\text { negative } \\
\text { sites } \\
\end{array}$ & $\begin{array}{c}0 \text { positive } \\
\text { site and } \\
101 \\
\text { negative } \\
\text { sites }\end{array}$ \\
\hline \multicolumn{19}{|c|}{ Fixed Effect Likelihood (FEL) } \\
\hline $\begin{array}{l}\text { No. of positive } \\
\text { and negative } \\
\text { selection sites } \\
\text { along with } \\
\text { codon position }\end{array}$ & $\begin{array}{l}1 \text { positive } \\
\text { site }(401) \\
\text { and } 65 \\
\text { negative } \\
\text { sites }\end{array}$ & $\begin{array}{l}2 \text { positive } \\
\text { sites }(28, \\
85) \text { and } 36 \\
\text { negative } \\
\text { sites }\end{array}$ & $\begin{array}{c}0 \text { positive } \\
\text { sites and } \\
47 \\
\text { negative } \\
\text { sites }\end{array}$ & $\begin{array}{l}3 \text { positive } \\
\text { sites }(10, \\
179,509) \\
\text { and } 55 \\
\text { negative } \\
\text { sites }\end{array}$ & $\begin{array}{l}2 \text { positive } \\
\text { sites }(213, \\
338) \text { and } 76 \\
\text { negative } \\
\text { sites }\end{array}$ & $\begin{array}{c}0 \text { positive } \\
\text { site and } \\
109 \\
\text { negative } \\
\text { sites }\end{array}$ & $\begin{array}{c}1 \\
\text { positive } \\
\text { site }(21) \\
\text { and } 61 \\
\text { negative } \\
\text { sites }\end{array}$ & $\begin{array}{c}0 \\
\text { positive } \\
\text { site and } \\
55 \\
\text { negative } \\
\text { sites }\end{array}$ & $\begin{array}{c}0 \\
\text { positive } \\
\text { site and } \\
67 \\
\text { negative } \\
\text { sites }\end{array}$ & $\begin{array}{c}7 \\
\text { positive } \\
\text { site }(34, \\
48,299, \\
287, \\
295, \\
302, \\
342) \text { and } \\
89 \\
\text { negative } \\
\text { sites } \\
\end{array}$ & $\begin{array}{c}1 \\
\text { positive } \\
\text { site } \\
(267) \\
\text { and } 79 \\
\text { negative } \\
\text { sites }\end{array}$ & $\begin{array}{c}5 \\
\text { positive } \\
\text { sites }(89 \\
237569 \\
1191 \\
1723) \\
\text { and } 159 \\
\text { negative } \\
\text { sites }\end{array}$ & $\begin{array}{c}1 \\
\text { positive } \\
\text { site } \\
(168) \\
\text { and 32 } \\
\text { negative } \\
\text { sites }\end{array}$ & $\begin{array}{c}1 \\
\text { positive } \\
\text { site (57) } \\
\text { and 93 } \\
\text { negative } \\
\text { sites }\end{array}$ & $\begin{array}{c}0 \\
\text { positive } \\
\text { site and } \\
31 \\
\text { negative } \\
\text { sites }\end{array}$ & $\begin{array}{c}5 \\
\text { positive } \\
\text { sites } \\
(114, \\
202, \\
356, \\
378, \\
400) \text { and } \\
104 \\
\text { negative } \\
\text { sites } \\
\end{array}$ & $\begin{array}{c}3 \\
\text { positive } \\
\text { sites }(46, \\
199, \\
351) \text { and } \\
86 \\
\text { negative } \\
\text { sites }\end{array}$ & $\begin{array}{c}11 \text { positive } \\
\text { sites }(61, \\
387,560, \\
598,623, \\
645,666, \\
848,900, \\
1191,1565) \\
\text { and } 112 \\
\text { negative } \\
\text { sites }\end{array}$ \\
\hline \multicolumn{19}{|c|}{ Internal Branch Fixed Effect Likelihood (IFEL) } \\
\hline $\begin{array}{l}\text { No. of positive } \\
\text { and negative } \\
\text { selection sites } \\
\text { along with } \\
\text { codon position }\end{array}$ & $\begin{array}{l}0 \text { positive } \\
\text { site and } 14 \\
\text { negative } \\
\text { sites }\end{array}$ & $\begin{array}{c}3 \text { positive } \\
\text { sites }(28 \\
85,181) \\
\text { and } 9 \\
\text { negative } \\
\text { sites }\end{array}$ & $\begin{array}{l}0 \text { positive } \\
\text { site and } \\
15 \\
\text { negative } \\
\text { sites }\end{array}$ & $\begin{array}{c}2 \text { positive } \\
\text { sites } \\
(10,457) \\
\text { and } 13 \\
\text { negative } \\
\text { sites }\end{array}$ & $\begin{array}{c}1 \text { positive } \\
\text { site }(390) \\
\text { and } 88 \\
\text { negative } \\
\text { sites }\end{array}$ & $\begin{array}{c}1 \text { positive } \\
\text { site } \\
(1261) \\
\text { and } 159 \\
\text { negative } \\
\text { sites }\end{array}$ & $\begin{array}{c}0 \\
\text { positive } \\
\text { site and } \\
80 \\
\text { negative } \\
\text { sites }\end{array}$ & $\begin{array}{c}1 \\
\text { positive } \\
\text { site } \\
(203) \\
\text { and } 63 \\
\text { negative } \\
\text { sites }\end{array}$ & $\begin{array}{c}2 \\
\text { positive } \\
\text { sites (12, } \\
299) \text { and } \\
88 \\
\text { negative } \\
\text { sites }\end{array}$ & $\begin{array}{c}9 \\
\text { positive } \\
\text { sites }(34, \\
48,154, \\
299, \\
287, \\
295, \\
299, \\
302, \\
342) \text { and } \\
97 \\
\text { negative } \\
\text { sites }\end{array}$ & $\begin{array}{c}3 \\
\text { positive } \\
\text { sites } \\
(201, \\
267, \\
399) \text { and } \\
85 \\
\text { negative } \\
\text { sites }\end{array}$ & $\begin{array}{c}11 \\
\text { positive } \\
\text { sites }(64, \\
89167, \\
237, \\
401, \\
569,784, \\
982, \\
1191, \\
1534, \\
1723) \\
\text { and } 181 \\
\text { negative } \\
\text { sites } \\
\end{array}$ & $\begin{array}{c}2 \\
\text { positive } \\
\text { sites } \\
(168, \\
296) \text { and } \\
62 \\
\text { negative } \\
\text { sites }\end{array}$ & $\begin{array}{c}1 \\
\text { positive } \\
\text { site (57) } \\
\text { and 57 } \\
\text { negative } \\
\text { sites }\end{array}$ & $\begin{array}{c}1 \\
\text { positive } \\
\text { site } \\
(111) \\
\text { and } 69 \\
\text { negative } \\
\text { sites }\end{array}$ & $\begin{array}{c}7 \\
\text { positive } \\
\text { sites }(17, \\
68,114, \\
202, \\
356, \\
378, \\
400) \text { and } \\
73 \\
\text { negative } \\
\text { sites }\end{array}$ & $\begin{array}{c}3 \\
\text { positive } \\
\text { sites }(46, \\
199, \\
351) \text { and } \\
90 \\
\text { negative } \\
\text { sites }\end{array}$ & $\begin{array}{c}13 \text { positive } \\
\text { sites }(61, \\
387,560, \\
598,623, \\
645,666, \\
848,900, \\
1191,1243, \\
1406, \\
1565) \text { and } \\
167 \\
\text { negative } \\
\text { sites }\end{array}$ \\
\hline
\end{tabular}


Table 12: The statistical outcomes and detailed information of two recombinant events which observed in recombination analysis of so far reported Avian avulavirus 1

\begin{tabular}{|c|c|c|}
\hline Analysis & Breakpoint 1 & Breakpoint 2 \\
\hline Potential recombinant isolate & JX854452 (Pheasant/MM20/Pakistan/ 2011) & JX854452 (Pheasant/MM20/Pakistan/ 2011) \\
\hline Potential major parent & KP776462 (chicken/NDV/Pak/AW-14) & KP776462 (chicken/NDV/Pak/AW-14) \\
\hline Similarity with major parent & $97.4 \%$ & $98.3 \%$ \\
\hline Potential minor parent & JN682210 (Chicken/BY/Pakistan/2010) & JN682210 (Chicken/BY/Pakistan/2010) \\
\hline Similarity with minor parent & $99 \%$ & $99.5 \%$ \\
\hline Region derived from major parent & $1-1007 \mathrm{nt}, 3475-15233 \mathrm{nt}$ & $1-8817 \mathrm{nt}, 9593-15219 \mathrm{nt}$ \\
\hline Region derived from minor parent & $1008-3474 \mathrm{nt}$ & $8818-9592 \mathrm{nt}$ \\
\hline Beginning breakpoint & $1006 \mathrm{nt}$ & $8793 \mathrm{nt}$ \\
\hline Beginning breakpoint $99 \%$ C.I & $974-1038 \mathrm{nt}$ & $8764-8808 \mathrm{nt}$ \\
\hline Ending breakpoint & $3448 \mathrm{nt}$ & $9566 \mathrm{nt}$ \\
\hline Ending breakpoint $99 \%$ C.I & $3368-3511 \mathrm{nt}$ & $9548-9654 \mathrm{nt}$ \\
\hline Length of recombination event & $2442 \mathrm{nt}$ & $774 \mathrm{nt}$ \\
\hline Probability (MC corrected) & $8.733 \mathrm{E}-160$ & $3.529 \mathrm{E}-84$ \\
\hline \multicolumn{3}{|l|}{ Indication of true recombination } \\
\hline Methods & Average $p$-value & Average $p$-value \\
\hline RDP & $1.729 \times 10^{-164}$ & $5.719 \times 10^{-83}$ \\
\hline GENECONV & $5.924 \times 10^{-158}$ & $4.769 \times 10^{-86}$ \\
\hline BootScan & $3.884 \times 10^{-161}$ & $9.267 \times 10^{-84}$ \\
\hline MaxChi & $1.023 \times 10^{-43}$ & $6.312 \times 10^{-20}$ \\
\hline Chimaera & $6.108 \times 10^{-45}$ & $1.743 \times 10^{-20}$ \\
\hline SiScan & $8.836 \times 10^{-52}$ & $5.074 \times 10^{-22}$ \\
\hline $3 \mathrm{Seq}$ & $2.247 \times 10^{-13}$ & $8.988 \times 10^{-13}$ \\
\hline
\end{tabular}

